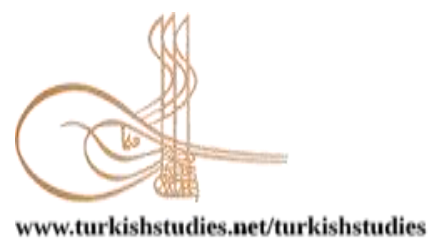

Turkish Studies

\title{
Öğretmen Görüşlerine Göre, Covid-19 Küresel Salgını Döneminde Gerçekleştirilen Uzaktan Eğitim Sürecinin Değerlendirilmesi
}

\author{
Investigation of the Distance Education Process by the Teachers 'Opinions in the Period of the \\ Covid-19 Pandemia
}

\author{
Serkan Demir* - Mustafa Kale**
}

\begin{abstract}
The aim of this study is to examine the opinions of teachers about the distance education process in the course of Covid-19 global epidemic, to reveal the positive and negative aspects of distance education and to make suggestions for the improvement of distance education. The research was carried out with case study (case study model), one of the screening models. The study group of the research consists of 44 teachers who work as preschool, primary, secondary and special education teachers in Ankara. In the research, the data were realized by applying online through a structured interview form developed by the researchers. The collected data were analyzed by content analysis. Themes and codes were created from the answers given to the interview questions and frequency distributions were determined. As a result of the research, it has been determined that the majority of teachers find themselves sufficient and moderate enough in distance education, many of those who do not have experience and proficiency develop themselves and increase their competence in the distance education process, while some teachers consider themselves inadequate. More than half of the teachers have expressed their views that the infrastructure is sufficient and some teachers have had difficulties in accessing distance education especially due to the deficiencies resulting from the students' current opportunities. The most problematic situations regarding access to distance education; that students have difficulties in accessing distance education due to lack of internet, lack of hardware tools, lack of technological knowledge of parents and individual characteristics of their students; It has been determined that especially the students in small age groups and students with special needs face various difficulties and limitations, their motivation and attention to the lessons are less, and the distance education process is adversely affected due to infrastructure problems. In online education, it is not possible to establish eye contact with the student, the parents support the distance education process to a large extent, the awareness of distance education, the status of parents to support the distance education process vary depending on the situations such as work intensity, the curriculum is not fully implemented, some courses and gains are not covered by distance education. It has been determined that they do not allow to practice,
\end{abstract}

*Dr., T.C. Milli Eğitim Bakanlığı, Şehit Emre Tunca İlkokulu
Dr., Ministry of National Education, Şehit Emre Tunca Primary School
ORCiD 0000-0002-0478-1831
serkandemirgazi @ gmail.com
${ }^{* *}$ Doç. Dr., Gazi Üniversitesi, Eğitim Fakültesi, Sınıf Eğitimi Anabilim Dalı
Asssociate Prof. Dr., Gazi University, Faculty of Education, Classroom Education Department
ORCiD 0000-0002-3727-1475
mkale@ gazi.edu.tr
Cite as/ Atıf: Demir, S. \& Kale M. (2020). Öğretmen görüşlerine göre, Covid-19 küresel salgını döneminde
gerçekleștirilen uzaktan eğitim sürecinin değerlendirilmesi. Turkish Studies, 15(8), 3445-3470. https://dx doi.org/10.7827/TurkishStudies.44492

Received/Geliş: 24 June/Haziran 2020

Accepted/Kabul: 20 December/Aralık 2020

Checked by plagiarism software

Copyright $($ ) MDE, Turkey 
lack of communication, interaction and feedback with distance education, access to all students, technology addiction, still life and health problems, low motivation of students. Distance education has positive aspects such as offering educational opportunities and opportunities, supporting face-to-face education, saving time and space, and affecting students psychologically, socially and physically negatively in the distance education process; It was determined that he had a chance to spend. In extraordinary situations that require students to stay at home, it is recommended to develop activity programs that can protect their psychological, social and physical health in the distance education process and to gain the necessary competencies to the students beforehand.

Structured Abstract: Introduction: COVID-19 spread rapidly all over the world and as of June 15, more than 7.5 million people were affected according to the World Health Organization (WHO) data and about 400 thousand people died due to this reason (WHO, 2020). In Turkey, 178 thousand more than the human virus has picked up, 4800 has lost more than human life (Ministry of Health, 2020) .400 Covidien causing the death of more than a thousand people-19 World Health Organization (WHO) by pandemic (global epidemic), respectively (WHO, 2020).

Covid-19 global epidemic, which affects many areas such as health, economy, tourism, art, sports, trade, industry in the world, has directly affected education. According to the United Nations Educational, Scientific and Cultural Organization data, schools have been closed in many countries of the world, approximately $70 \%$ of students have been affected by this process (UNESCO, 2020). Due to the global epidemic, face-to-face education has been paused around the world and millions of students have started to receive distance education (Can, 2020).

In Turkey, the Ministry of National Education (MONE), students have set up a distance education system in terms of academic and social support, psychosocial spent his life support system (Özer, 2020), although; Covidien-19 with global outbreak quickly entered our lives, especially how distance education process being carried out in Turkey, more online media which are used, is not known as to what is encountered positive and negative processes. In this sense, determining the opinions of teachers about the distance education process is important in terms of improving and developing the distance education system. The aim of this study is to examine the opinions of teachers about the distance education process in depth, to reveal the positive and negative aspects of distance education and to make suggestions for the improvement of distance education.

\section{Method}

The research was carried out with case study (case study model), one of the screening models. The study group of the research consists of 44 teachers who work as preschool, primary, secondary and special education teachers in Ankara.

In the research, the data were realized by applying online through a structured interview form developed by the researchers. The collected data were analyzed by content analysis. Themes and codes were created from the answers given to the interview questions and frequency distributions were determined.

During the distance education, MEB carried out studies to meet the personal development and psychological needs of students through Education Information Network, TRT, social media and teachers. The fact that teachers can teach live lessons through the Education Information Network and that students can follow their lessons at scheduled times contributed to the distance education process. However, it has been stated by teachers that there are probelms for planning sufficient lesson hours for all students, especially in the first time due to lack of infrastructure problems, some students could not be included in the educational content due to the lack of internet and hardware tools.

\section{Results and Conclusion}

As a result of the research, it has been determined that the majority of teachers find themselves sufficient and moderate enough in distance education, many of those who do not have experience and proficiency develop themselves and increase their competence in the distance education process, while some teachers consider themselves inadequate.

More than half of the teachers have expressed their views that the infrastructure is sufficient and some teachers have had difficulties in accessing distance education especially due to the deficiencies resulting from the students' current opportunities.

Turkish Studies, 15(8) 
The most problematic situations regarding access to distance education; that students have difficulties in accessing distance education due to lack of internet, lack of hardware tools, lack of technological knowledge of parents and individual characteristics of their students; It has been determined that especially the students in small age groups and students with special needs face various difficulties and limitations, their motivation and attention to the lessons are less, and the distance education process is adversely affected due to infrastructure problems.

In online education, it is not possible to establish eye contact with the student, the parents support the distance education process to a large extent, the awareness of distance education, the status of parents to support the distance education process vary depending on the situations such as work intensity, the curriculum is not fully implemented, some courses and gains are not covered by distance education. It has been determined that they do not allow to practice, lack of communication, interaction and feedback with distance education, access to all students, technology addiction, still life and health problems, low motivation of students.

Distance education has positive aspects such as offering educational opportunities and opportunities, supporting face-to-face education, saving time and space, and affecting students psychologically, socially and physically negatively in the distance education process. It was determined that he had a chance to spend.

In extraordinary situations that require students to stay at home, it is recommended to develop activity programs that can protect their psychological, social and physical health in the distance education process and to gain the necessary competencies to the students beforehand.

Keywords: Educational Sciences, Education Management, Covid-19, Distance Education, Teacher Opinions

Öz: $\mathrm{Bu}$ araştırmanın amacı Covid-19 küresel salgını döneminde öğretmenlerin uzaktan eğitim süreci hakkındaki görüşlerini derinlemesine incelemek, uzaktan eğitimin olumlu ve olumsuz yanlarını ortaya çıkarmak ve uzaktan eğitimin iyileştirilmesi için önerilerde bulunmaktır. Araştırma tarama modellerinden durum çalışması (örnek olay tarama modeli) ile gerçekleştirilmiştir. Araştırmanın çalışma grubunu Ankara'da resmi okulöncesi, ilkokul, ortaokul ve özel eğitim kurumlarında görev yapmakta olan toplam 44 öğretmen oluşturmaktadır. Araştırmada veriler, araştırmacılar tarafından geliştirilen yapılandırılmış görüşme formu ile çevrimiçi ortamda uygulanarak toplanmıştır. Araştırma verilerinin toplanması aşamasında, Gazi Üniversitesi'ne etik kurul izni için başvurulmuş ve araştırma için 11.12.2020 tarih ve E.133138 say1lı etik kurul onayı alınmıştır. Toplanan veriler içerik analizi ile analiz edilmiştir. Görüşme sorularına verilen cevaplardan tema ve kodlar oluşturulmuş, frekans dağılımları belirlenmiştir. Araştırma sonucunda öğretmenlerin büyük çoğunluğunun uzaktan eğitim konusunda kendini yeterli ve orta düzeyde yeterli gördüğü, deneyimi ve yeterliği olmayanların birçoğunun ise uzaktan eğitim süreci içerisinde kendilerini geliştirdikleri ve yeterliklerini artırdıkları, bazı öğretmenlerin ise kendisini yetersiz gördüğü belirlenmiştir. Öğretmenlerin yarısından fazlası alt yapının yeterli olduğu, bazı öğretmenler ise özellikle öğrencilerin mevcut imkânlarından kaynaklanan eksiklikler sebebiyle uzaktan eğitime erişim konusunda sıkıntı yaşandı̆̆ görüşlerini ortaya koymuştur. Uzaktan eğitime erişim konusunda en fazla problem yaşanan durumların; öğrencilerin internetlerinin olmaması, öğrencilerin donanımsal araçlarının yetersizliği, velilerin teknolojik bilgi eksikliği, öğrencilerinin bireysel özellikleri sebebiyle uzaktan eğitime erişim konusunda sıkıntı yaşandığı; özellikle küçük yaş gruplarındaki öğrenciler ile özel gereksinimli öğrencilerin çeşitli zorluklarla ve kısıtlılıklarla karşılaştığı, öğrencilerin motivasyonlarının ve derse olan dikkatlerinin daha düşük olduğu, alt yapıdan kaynaklanan sorunlar sebebiyle uzaktan eğitim sürecinin olumsuz yönde etkilendiği belirlenmiştir. Çevrimiçi olarak yapılan eğitimlerde öğrenci ile göz teması kurulamadığı, velilerin büyük ölçüde uzaktan eğitim sürecine destek olduğu, uzaktan eğitime ilişkin farkındalık, velilerin iş yoğunluğu gibi durumlara bağlı olarak uzaktan eğitim sürecini destekleme durumlarının değişkenlik gösterdiği, müfredatın tam anlamıyla uygulanamadığı, bazı derslerin ve kazanımların uzaktan eğitimle uygulama yapmaya imkân vermediği, uzaktan eğitimle yeterli iletişim, etkileşim ve geri dönüt sağlanamaması, öğrencilerin tümüne erişim sağlanamaması, teknoloji bağımlılı̆̆ı, hareketsiz yaşam ve sağlık sorunlarına sebep olması, öğrencilerin motivasyonlarının düşük olması gibi olumsuz yanlarının olduğu belirlenmiştir. Uzaktan eğitimin küresel salgın döneminde farklı eğitim firsatları ve imkânları sunması, yüz yüze eğitimi desteklemesi, zamandan ve mekândan tasarruf sağlaması gibi olumlu yanlarının olduğu ortaya konulmuştur. Öğrencilerin uzaktan eğitim sürecinde psikolojik, sosyal ve fiziksel açıdan olumsuz yönde etkilendiği, bununla birlikte bu süreçte aileleriyle daha fazla vakit geçirme şansı bulduğu belirlenmiştir. Öğrencilerin evde kalmasını gerektirecek 
olağanüstü durumlarda uzaktan eğitim sürecinde psikolojik, sosyal ve fiziksel anlamda sağlığını koruyabileceği etkinlik programlarının geliştirilmesi ve öncesinde öğrencilere gereken yeterliklerin kazandırılması önerilmektedir.

Anahtar Kelimeler: Eğitim Bilimleri, Eğitim Yönetimi, Covid-19, Uzaktan Eğitim, Öğretmen Görüşleri.

\section{Giriş}

İnsanlık tarihi boyunca, ölümlere yol açan birçok doğal afet ya da salgın hastalık görülmüştür. Salgın hastalıları oluşturan en önemli etken virüslerdir. Geçmişte insanların ölümüne neden olan ve Koronavirüs ailesinde yer alan, 2002'de uzak doğuda SARS, 2012'de Suudi Arabistan'da MERS salgınları yaşanmıştır. Yine aynı virüs ailesinden yeni Koronavirus ilk defa Aralık 2019'da Çin'in Wuhan şehrindeki bazı insanlarda akut solunum yetmezliği sendromu tespit edildiğinin açıklanmasıyla saptanmıştır. Hastalardan alınan örneklerin incelenmesi sonucunda 7 Ocak'ta, hastalığa neden olan virüsün Koronavirus ailesinden olduğu anlaşıllmış ve virüse Yeni Koronavirus 2019 (2019-nCoV) adı verilmiştir. Yeni Koronavirus resmi olarak SARS-CoV-2 olarak adlandırılmış, yol açtığı hastalığın adı Covid-19 olarak belirlenmiştir (Sari Yanartaş ve Hancerli Torun, 2020).

Tüm dünyada Covid-19 hızlıca yayılmış ve 15 Haziran itibariyle Dünya Sağlık Örgütü (DSÖ) verilerine göre 7,5 milyondan fazla insan etkilenmiş ve yaklaşık 400 bin kişi bu sebeple vefat etmiştir (WHO, 2020). Türkiye'de de 178 binden fazla insan virüsü kapmış, 4800 den fazla insan hayatını kaybetmiştir (Sağlık Bakanlığı, 2020).400 binden fazla insanın ölümüne neden olan Covid-19 Dünya Sağlık Örgütü (DSÖ) tarafından pandemi (Küresel salgın) olarak tanımlanmıştır (WHO, 2020).

Covid-19 küresel salgını, tüm dünyayı etkisi altına alan ve Ebola, MERs, SARs gibi salgınlardan daha büyük bir salgın olarak kabul edilmektedir (Yılmaz, 2020). Gelişmiş ve gelişmekte olan ülkelerin, henüz aşı ve ilaç geliştirilmemesi sebebiyle çaresiz kaldığı Covid-19 virüsünün dünyadaki etkisini tam olarak ne zaman yitireceği kestirilememektedir.

Dünyada sağlık, ekonomi, turizm, sanat, spor, ticaret, sanayi gibi birçok alanı etkileyen Covid-19 küresel salgını, eğitimi de doğrudan etkilemiştir. Birleşmiş Milletler Eğitim, Bilim ve Kültür Örgütü verilerine göre, dünyanın pek çok ülkesinde okullar kapatılmış, öğrencilerin yaklaşık \% 70'i bu süreçten etkilenmiştir (UNESCO, 2020). Küresel salgın nedeniyle, dünya genelinde yüz yüze eğitim duraklatılmış, milyonlarca öğrenci uzaktan eğitim görmeye başlamıştır (Can, 2020).

Türkiye'de Cumhurbaşkanlığınca yayımlanan genelge kapsamında (T.C. Resmi Gazete, 2020a) Milli Eğitim Bakanlığı tarafından eğitim ve öğretim faaliyetlerinin uzaktan eğitim yöntemiyle gerçekleştirileceği (MEB, 2020a), kararı alınmıştır. Millî Eğitim Bakanlığı, Covid-19 küresel salgını kapsamında idari izin, dönüşümlü ve uzaktan çalışmaya ilişkin usul ve esasları (MEB, 2020b) düzenlemiş ve böylece resmi olarak uzaktan eğitimin yol haritası ortaya konulmuştur. $\mathrm{Bu}$ yol haritasına uygun olarak uzaktan eğitim 18.108.860 öğrenci ve 1.077.307 öğretmeni ile tüm Türkiye'de başlatılmıştır (MEB, 2019).

Covid-19 küresel salgını nedeniyle hem dünya genelinde hem de Türkiye özelinde ani bir şekilde başlanan uzaktan eğitimin dünyadaki ilk uygulamalarının, 1728 yılında Boston gazetesinde yayımlanan "Steno Dersleri”" ilanı ile başladığı belirtilmektedir (Telli Yamamoto ve Altun, 2020). Türkiye'de ise uzaktan eğitim tartışmaları 1923 yılından sonra başlamış, 1970'li yıllarda orta eğitim düzeyini, 1980 sonrası yükseköğretimi, 1990’lı yıllarda ilk, orta ve yükseköğretimi kapsayarak uzaktan eğitim, büyük öğrenci kitlelerini bünyesinde barındıran bir sistem haline gelmiştir (Bozkurt, 2017).

Okullar açısından bakıldığında, uzaktan eğitim öğrenci, öğretmen ve öğrenme kaynakları arasındaki sınırlılıkları ortadan kaldırmak için mevcut teknolojileri pragmatist bir yaklaşımla 
kullanan disiplinler arası bir alan olarak tanımlayan Bozkurt (2017), Türkiye'de uzaktan eğitim sürecini dört dönem halinde Şekil 1'deki gibi belirtmiştir.

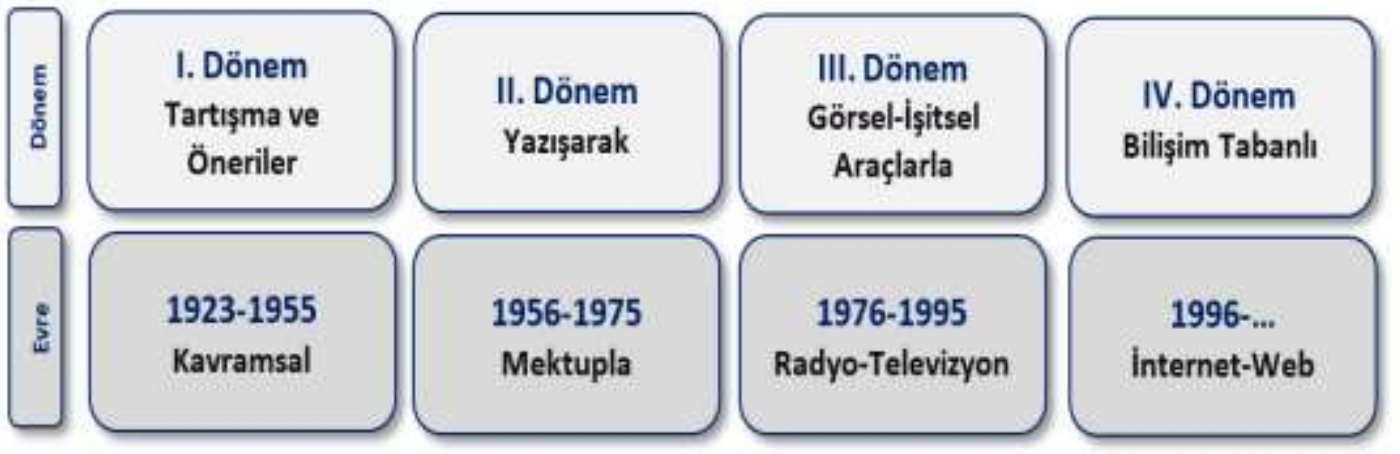

Şekil 1: Uzaktan Eğitimin Türkiye Bağlamında Dönem ve Evreleri.

Mektup, radyo, televizyon, internet-web vb. yöntemlerle insan hayatında yerini alan uzaktan eğitim süreçleri şüphesiz tüm toplumları Covid-19 küresel salgınıyla birlikte daha fazla etkisi altına almıştır. Özellikle günümüzde bilişim tabanlı yaklaşımlarla farklı çevrim içi ortam uygulamaları uzaktan eğitim sürecine dâhil olmuştur. Çevrim içi öğrenme ortamları, öğrencilerin ve öğretmenlerin birbirleriyle iletişim kurup çevrim içi teknolojiler yoluyla ders içerikleriyle etkileşimde bulunduğu ortamlardır (Bolliger ve Wasilik, 2009; Miltiadou ve Yu, 2000; Yıldız ve Seferoğlu, 2020). Bu ortamlarda öğreticiler diğer katılımcılarla ve öğretmenle gerek eşzamanlı gerekse eşzamanlı olmayan çevrim içi iletişim araçlarını kullanarak etkileşim kurmaktadırlar (Wang, 2008). Türkiye'de TRT ve Milli Eğitim Bakanlığı iş birliği ile Eğitim Bilişim Ağı (EBA) üzerinden uzaktan eğitim süreçleri yönetilmektedir. EBA üzerinden tüm sınıf seviyelerine eğitim verilmekte fakat karşılaşılan sorunlar sebebiyle farklı çevrim içi uygulamalara da gereksinim duyulmaktadır. Milli Eğitim Bakanlığı tarafından EBA Canlı Ders uygulamasının ülke genelinde kullanıma açılmasına kadar EBA dışındaki Zoom, Teams, Hangouts, Meet, Skype ve benzeri platformların ücretsiz olanlarıyla sanal sınıf uygulamalarının kullanımına izin verilmiştir (MEB, 2020c).

Uzaktan eğitim süreçlerinde birçok çevrim içi teknolojileri kullanmada çeşitli güçlüklerle karşılaşılmaktadır (Altıparmak, Kurt ve Kapıdere, 2011; Miltiadou ve Yu, 2000). Aynı zamanda Covid-19'un yol açtığı olumsuz psikolojik etkiler ile başa çıkmak için MEB, yardım hattı ve rehberlerden oluşan bir psikososyal destek sistemi kurmuştur. Sonuç olarak MEB, öğrencileri akademik ve sosyal açıdan destekleyen bir uzaktan eğitim sistemi kurmuş, psikososyal destek sistemini hayata geçirmiş (Özer, 2020) olmasına rağmen Covid-19 küresel salgını ile birlikte hızı bir şekilde hayatımıza giren uzaktan eğitim süreci, özellikle Türkiye'de nasıl yürütülmekte, daha çok hangi çevrim içi ortamlar kullanılmakta, ne gibi olumlu ve olumsuz süreçlerle karşılaşılmakta bilinmemektedir. $\mathrm{Bu}$ anlamda öğretmenlerin uzaktan eğitim süreci hakkındaki görüşlerinin belirlenmesi uzaktan eğitim sisteminin iyileştirilmesi ve geliştirilmesi açısından önemlidir. $\mathrm{Bu}$ araştırmanın amacı öğretmenlerin uzaktan eğitim süreci hakkındaki görüşlerini derinlemesine incelemek, uzaktan eğitimin olumlu ve olumsuz yanlarını ortaya çıkarmak ve uzaktan eğitimin iyileştirilmesi için önerilerde bulunmaktır. Bu amaca ulaşabilmek için aşağıdaki sorulara cevap aranmıştır.

- Uzaktan eğitimle ilgili bilgi, deneyim ve yeterlik durumunuzu nasıl değerlendirirsiniz?

- Teknolojiye erişim ve uzaktan eğitimin alt yapı yeterlikleri konusunu nasıl değerlendirirsiniz?

- Sizin ve öğrencilerinizin teknolojiye erişim konusunda karşılaştı̆̆ınız problemleri nasıl değerlendirirsiniz?

- Öğrencilerinizin ders işleme sırasındaki motivasyon ve derse katılım durumlarını nasıl değerlendirirsiniz? 
- Velilerin uzaktan eğitim sürecine destek ve katılım durumlarını nasıl değerlendirirsiniz?

- Dezavantajlı durumda olan öğrencilerinizin uzaktan eğitimden yararlanma süreçlerini nasıl değerlendirirsiniz?

- Uzaktan eğitim sürecinde, müfredatın uygulanması ve derslerin işleniş sürecini nasıl değerlendirirsiniz?

- Sizce uzaktan eğitim-öğretim faaliyetlerinin olumlu ve olumsuz yanları nelerdir?

- Uzaktan eğitim sürecinde evde kalmak zorunda olan öğrencilerinizin (sosyal, fiziksel ve psikolojik) durumlarını olumlu/olumsuz yönleriyle nasıl değerlendirirsiniz?

- Yüz yüze eğitim ile uzaktan eğitimi karşılaştıracak olursanız neler söylersiniz?

\section{Yöntem}

Araştırma tarama modellerinden durum çalışması (örnek olay tarama modeli) ile gerçekleştirilmiştir. Nitel araştırma yaklaşımları içerisinde durum çalışması araştırmacıya bir olaya müdahale etmeden derinlemesine inceleme, anlama ve birey, katılımc1 ya da toplum üzerindeki etkisi ya da ilişkisi konusunda çıkarımlarda bulunma fırsatı sunmaktadır. Dolayısıyla durum çalışması, incelenen güncel bir duruma özgü olarak nasıl ya da neden soru kipleriyle başlayan sorulara cevap arayan, araştırmacıya derinlemesine zengin veri toplama olanağı sağlayan görgül bir araștırma türüdür (Yin, 2014'ten aktaran Saban ve Ersoy, 2016). Araștırmanın çalıșma grubu, Ankara ilinde, amaçlı örnekleme yöntemlerinden gözlem birimlerinin belirli niteliklere sahip olmasını gerektiren ölçüt örnekleme kullanılarak belirlenmiştir (Büyüköztürk, Kılıç Çakmak, Akgün, Karadeniz ve Demirel, 2018, s.95). Çalışma grubunun resmi okullarda görevli okulöncesi öğretmenlerinden 10, İlkokul öğretmenlerinden 20, ortaokul öğretmenlerinden 10 ve lise öğretmenlerinden 10 kişi olmak üzere, uzaktan eğitim sürecinde ders veren, gönüllülük esasına göre araştırmaya katılmak isteyen ve araştırma onamını kabul eden öğretmenler arasından belirlenmesi hedeflenmiştir. Çalışma grubuna her eğitim kademesinden öğretmenler dâhil edilerek hem uzaktan eğitime ilişkin tüm tarafların görüşünü yansıtmak hem de veride çeşitliliği sağlamak amaçlanmıştır. Hedeflenen çalışma grubu okulöncesi 9, ilkokul 20, ortaokul 10 ve özel eğitim 5 olmak üzere toplam 44 öğretmenle sınırlı kalmıștır. Lise öğretmenleri arasından katılım olmaması araştırmanın bir sınırlılığıdır. Çalışma grubunda yer alan öğretmenlere ilişkin bilgiler Tablo 1'de sunulmuştur.

Tablo 1:Uzaktan Eğitime Katılan Öğretmenlere İlişkin Demografik Bilgiler

\begin{tabular}{|c|c|c|c|}
\hline Özellikler & & Sayı (N) & Toplam (N) \\
\hline \multirow{3}{*}{ Cinsiyet } & Erkek & 14 & \multirow{3}{*}{44} \\
\hline & Kadın & 30 & \\
\hline & $1-5$ Yil & 9 & \\
\hline \multirow{5}{*}{ Hizmet süresi } & 6-10 Yil & 18 & \multirow{5}{*}{44} \\
\hline & $11-15 Y_{11}$ & 9 & \\
\hline & $16-20$ Y1l & 7 & \\
\hline & 21 Yil ve üzeri & 1 & \\
\hline & Lisans & 30 & \\
\hline \multirow{3}{*}{ Öğrenim düzeyi } & Yüksek lisans & 13 & \multirow[t]{3}{*}{44} \\
\hline & Doktora & 1 & \\
\hline & Anaokulu/Anasınıfi & 9 & \\
\hline \multirow{3}{*}{$\begin{array}{l}\text { Görev yağtığı eğitim } \\
\text { kademesi }\end{array}$} & İlkokul & 20 & \multirow[t]{3}{*}{44} \\
\hline & Ortaokul & 10 & \\
\hline & Özel eğitim & 5 & \\
\hline
\end{tabular}

Tablo 1 incelendiğinde, çalışma grubunda 14 erkek ve 30 kadın öğretmenin bulunduğu, katılımcıların 9'unun okulöncesi, 20'sinin ilkokul, 10'unun ortaokul ve 5'inin özel eğitim öğretmeni olduğu, 9'unun 0-5 yıl, 18'inin 6-10 yıl, 9'unun 11-15 yıl, 7'sinin 16-20 y1l ve 1'inin 21 
yıldan daha fazla kıdeme sahip olduğu; yine katılımcıların 30'unun lisans, 13'ünün yüksek lisans ve 1'inin doktora diplomasına sahip olduğu görülmektedir.

Araştırmada verilerin toplanma süreci, araştırmacılar tarafından geliştirilen yarı yapılandırılmış görüşme formunun çevrimiçi ortamda uygulanması ile gerçekleştirilmiştir. Araştırma verilerinin toplanması aşamasında, Gazi Üniversitesi'ne etik kurul izni için başvurulmuş ve araştırma için 11.12.2020 tarih ve E.133138 sayılı etik kurul onayı alınmıştır. Yarı yapılandırılmış görüşme formundaki sorular oluşturulurken literatür taraması yapılmıştır. Geliştirilen form öncelikle taslak olarak hazırlanmış, eğitim bilimleri alanında 2 uzmandan görüş alınmıştır. Alınan görüşler sonrası 1 dil uzmanının incelemesi sonrası görüşme formu oluşturulmuştur. Görüşme formunda 10 adet açık uçlu soru bulunmaktadır. Toplanan veriler öncelikle düzenlenmiş, her soru bazında öğretmenlerin verdiği cevaplar incelenerek, göze çarpan kelime, cümle ya da olaylar araştırmacılar tarafından belirlenerek kodlar oluşturulmuştur. Güvenirlik, öğretmenlerle yapılan görüşmelerden sonra elde edilen verilerin, araştırmacılar tarafından kodlanması ve daha sonra Miles ve Huberman'ın (1994) belirttiği “Güvenirlik=Görüş birliği/Görüş Ayrılı̆̆ı 1 Görüş Birliği x 100" formülü ile hesaplanmıştır. Daha sonra veriler özetlenmiş, temalar oluşturulmuştur. Elde edilen kod ve temalar yorumlanarak içerik analizi gerçekleştirilmiştir. Öğretmenlerin uzaktan eğitim sürecinde kullandıkları iletişim araçları Tablo 2'de verilmiştir.

Tablo 2: Öğretmelerin Uzaktan Eğitim Sürecinde Kullandıkları İletişim Araçları

\begin{tabular}{lc}
\hline Illetişim şekli & Sayı (N) \\
\hline Telefonla Arama & 1 \\
Telefonla Arama ve Whatsap, telegram & 13 \\
Telefonla Arama ve Whatsap, telegram ve EBA canlı ders & 1 \\
Telefonla arama yaparak, Whatsapp, Telegram vb., Elektronik posta yoluyla & 3 \\
Telefonla arama yaparak, Whatsapp, Telegram vb., Youtube, Facebook vb. & 2 \\
Telefonla arama yaparak, Whatsapp, Telegram vb., Zoom, Skype, Adobe Connect vb. & 8 \\
Telefonla arama yaparak, Whatsapp, Telegram vb., Zoom, Skype, Adobe Connect vb., & 7 \\
Youtube, Facebook vb. & 2 \\
Whatsapp, Telegram vb. & 3 \\
Whatsapp, Telegram vb., Zoom, Skype, Adobe Connect vb. & 3 \\
Zoom, Skype, Adobe Connect vb. & 1 \\
Zoom, Skype, Adobe Connect vb., Elektronik posta yoluyla & 44 \\
\hline Toplam (N)
\end{tabular}

Tablo 2 incelendiğinde uzaktan eğitim sürecinde öğretmenlerin çoğunun birden fazla iletişim aracı ile öğrencilerle iletişim kurduğu, telefonla arama, Whatsap ve telegram gibi araçların çoğunlukla tercih edildiği, yine öğretmenlerin Telefonla arama yaparak, Whatsapp, Telegram vb., Zoom, Skype, Adobe Connect vb. gibi araçları çoğunlukla kullanmayı tercih ettikleri, yalnızca telefonla arama yaparak iletişim kuranların sayısının ise sınırlı olduğu görülmektedir.

\section{Bulgular}

Bulgular, katılımcıların 10 soruya verdikleri cevaplar doğrultusunda bu bölümde sunulmuştur. Katılımcılar, branşları bazında harf ve sayı ile farklı rumuzlarla isimlendirilmiştir (A1, İ1,O1,Ö1).

\section{Uzaktan Eğitimle İlgili Bilgi, Deneyim ve Yeterlik Durumunuzu Nasıl Değerlendirirsiniz? Sorusuna İlişkin Bulgular}

Öğretmenlerin, uzaktan eğitimle ilgili bilgi, deneyim ve yeterlik durumuna ilişkin bulugular Tablo 3'te verilmiştir. 
Oluşturulan kodlar incelendiğinde "Öğretmen Öz Yeterlik" temasında, anasınıfı öğretmenlerinin 3'ü kendini yeterli, 3'ü orta düzeyde yeterli, 2'si ise yetersiz gördüklerini, ilkokul öğretmenlerinin 6's1 kendini yeterli, 6's1 orta düzeyde yeterli, 6's1 ise yetersiz gördüklerini, ortaokul öğretmenlerinin 3'ü kendini yeterli, 3'ü orta düzeyde yeterli, 2'si ise yetersiz gördüklerini, özel eğitim öğretmelerinin 1'i orta düzeyde yeterli 2'si ise yetersiz gördüklerini belirtmiştir (Tablo3).

Tablo3: Öğretmenlerin Uzaktan Eğitim Yeterlik Durumuna İlişkin Veriler

\begin{tabular}{|c|c|c|c|c|c|c|c|}
\hline & Temalar & Kodlar & $\begin{array}{l}\text { Anasınıfi } \\
\text { Öğrt. /(f) }\end{array}$ & $\begin{array}{l}\text { İlkokul } \\
\text { Öğrt. / (f) }\end{array}$ & $\begin{array}{l}\text { Ortaokul } \\
\text { Öğrt. / (f) }\end{array}$ & $\begin{array}{l}\text { Özel } \\
\text { Eğitim } \\
\text { Öğrt. / (f) }\end{array}$ & Toplam (f) \\
\hline \multirow{3}{*}{1.} & \multirow{3}{*}{$\begin{array}{l}\text { Öğretmen } \\
\text { Öz yeterlik }\end{array}$} & 1-Yeterli & $\begin{array}{l}\text { A1, A2, } \\
\text { A5/ (3) }\end{array}$ & $\begin{array}{l}\text { İ5, İ6, İ7, } \\
\text { İ } 8 \text { İ14, } \\
\text { İ20/ (6) }\end{array}$ & $\begin{array}{l}\text { O2, O8, } \\
\text { O10/ (3) }\end{array}$ & - & 12 \\
\hline & & $\begin{array}{l}\text { 2-Orta } \\
\text { düzeyde } \\
\text { yeterli }\end{array}$ & $\begin{array}{l}\text { A3, A4, } \\
\text { A8/ (3) }\end{array}$ & $\begin{array}{l}\text { İ3, İ, İ9, } \\
\text { İ10, İ11, } \\
\text { İ12/ (6) }\end{array}$ & $\begin{array}{l}\text { O1, O6, O7/ } \\
\text { (3) }\end{array}$ & Ö3/ (1) & 13 \\
\hline & & $\begin{array}{l}3- \\
\text { Yetersiz }\end{array}$ & $\begin{array}{l}\text { A6, A7/ } \\
(2)\end{array}$ & $\begin{array}{l}\dot{\mathrm{I}} 1, \dot{\mathrm{I}} 2, \\
\mathrm{I} 13, \dot{\mathrm{I}} 15, \\
\dot{\mathrm{I}} 17, \dot{\mathrm{I}} 19 / \\
(6)\end{array}$ & $\mathrm{O} 3, \mathrm{O} 5 /(2)$ & $\begin{array}{l}\text { Ö1, Ö5/ } \\
\text { (2) }\end{array}$ & 12 \\
\hline
\end{tabular}

Öğretmenlerin uzaktan eğitimle ilgili bilgili, deneyim ve yeterliklerine ilişkin yazdıklarına bakıldığında; "Illk defa deneyimledim. Bu konuda kendimi yetersiz hissediyorum (A7)", "Herhangi bir sorun yaşamadim. Teknolojik olarak neredeyse tüm imkânları kullandım (ï)”, "Deneyim sahibi değildim. İlk kez uzaktan eğitim yaptım (İ17), "Orta yeterlilikte olduğumu düşünüyorum (O1)", "Deneyimsiz olduğumu düşünüyorum (Ö1)" ve "Başlangıçta yetersizdi, deneyimledikçe yeterliliğim arttı (Ö3)” ş̧eklinde görüşlerini ifade ettikleri görülmektedir.

$\mathrm{Bu}$ bulgular 1şığında öğretmenlerin büyük çoğunluğunun uzaktan eğitim konusunda kendini yeterli gördüğünü, deneyimi ve yeterliği olmayanların ise süreç içerisinde kendilerini geliştirdikleri ve yeterliklerini artırdıkları anlaşılmaktadır.

Teknolojiye Erişim ve Uzaktan Eğitimin Alt Yapı Yeterlikleri Konusunu Nasıl Değerlendirirsiniz? Sorusuna İliş̧kin Bulgular.

Öğretmenlerin teknolojiye erişim ve uzaktan eğitimin alt yap1 yeterlikleri konusundaki görüşlerine Tablo 4'te yer verilmiştir. 


\begin{tabular}{|c|c|c|c|c|c|c|c|}
\hline & Temalar & Kodlar & $\begin{array}{l}\text { Anasınıfı } \\
\text { Öğrt. (f) }\end{array}$ & $\begin{array}{l}\text { İlkokul } \\
\text { Öğrt. (f) }\end{array}$ & $\begin{array}{l}\text { Ortaokul } \\
\text { Öğrt. (f) }\end{array}$ & $\begin{array}{l}\text { Özel Eğitim } \\
\text { Öğrt. (f) }\end{array}$ & Toplam (f) \\
\hline \multirow[b]{3}{*}{1.} & \multirow[b]{3}{*}{$\begin{array}{l}\text { Alt yap1 } \\
\text { yeterlik } \\
\text { durumu }\end{array}$} & 1-Yeterli & $\mathrm{A} 1 /(1)$ & $\begin{array}{l}\text { İ2, İ4, } \\
\text { İ7/ (3) }\end{array}$ & $\begin{array}{l}\mathrm{O} 1, \mathrm{O} 2, \\
\mathrm{O} 4, \mathrm{O} 5, \\
\mathrm{O} 10 /(5)\end{array}$ & Ö2/ (1) & 10 \\
\hline & & $\begin{array}{l}\text { 2-Orta } \\
\text { düzeyde } \\
\text { yeterli }\end{array}$ & A9/ (1) & $\begin{array}{l}\text { İ14, } \\
\text { İ16, } \\
\text { İ18/ (3) }\end{array}$ & $\begin{array}{l}\text { O3, O6, } \\
\text { O7, O8, } \\
\text { O9/ (5) }\end{array}$ & $\begin{array}{l}\text { Ö1, Ö3, Ö4, } \\
\text { Ö5/ (4) }\end{array}$ & 13 \\
\hline & & 3-Yetersiz & $\begin{array}{l}\text { A3, A4, } \\
\text { A5, A6, } \\
\text { A7, A8/ (6) }\end{array}$ & $\begin{array}{l}\text { İं1, ப̇3, } \\
\text { İ5, İ6, } \\
\text { İ8, I9, } \\
\text { İ10, } \\
\text { İ11, } \\
\text { İ13, } \\
\text { İ15, } \\
\text { İ17, } \\
\text { İ19, } \\
\text { İ20/ } \\
(13)\end{array}$ & & & 19 \\
\hline \multirow{3}{*}{2.} & \multirow{3}{*}{$\begin{array}{l}\text { Öğrencilerin } \\
\text { teknolojiye } \\
\text { erişim durumu }\end{array}$} & $\begin{array}{l}\text { 1-Donanımsal } \\
\text { yetersizlik }\end{array}$ & $\begin{array}{l}\mathrm{A} 1, \mathrm{~A} 2, \\
\mathrm{~A} 3, \mathrm{~A} 7 /(4)\end{array}$ & & & & 4 \\
\hline & & $\begin{array}{l}\text { 2-İnternet } \\
\text { aboneliğinin } \\
\text { olmamas1 }\end{array}$ & $\begin{array}{l}\text { A3, A4, } \\
\text { A8/ (3) }\end{array}$ & & & & 3 \\
\hline & & $\begin{array}{l}\text { 3-Teknolojik } \\
\text { bilgi eksikliği }\end{array}$ & $\begin{array}{l}\text { A1, A2, } \\
\text { A3/ (3) }\end{array}$ & & & & 3 \\
\hline
\end{tabular}

Öğretmenlerden alınan görüşlere dayanarak bu konuda 2 tema oluşturulmuştur. "Alt yapı yeterlik durumu" temasında; yeterli (f:10), orta düzeyde yeterli (f:13), yetersiz (f:19) olmak üzere 3 adet kod belirlenmştir. "Öğrencilerin teknolojiye erişim durumu" temasında; Donanımsal yetersizlik (f:4), internet aboneliğinin olmaması (f:3), teknolojik bilgi eksikliği (f:3) olmak üzere 3 adet kod oluşturulmuştur. Oluşturulan kodlar incelendiğinde 19 öğretmen alt yapının yetersiz, 13 öğretmen orta düzeyde yeterli ve 10 öğretmen yeterli olarak nitelendirirken; öğrencilerin teknolojiye erişimi konusunda 4 öğretmen donanımsal açidan öğrencilerin yetersiz olduğu, 3 öğretmen internet aboneliklerinin bulunmadığı, 3 öğretmen ise öğrencilerin teknolojik açıdan bilgi eksiği olduğunu belirtmiştir (Tablo4).

Öğretmenlerin teknolojiye erişim ve uzaktan eğitimin alt yap1 yeterlikleri konusundaki yazdıklarına bakıldığında; "Maalesef bazı çocuklarımızın teknolojiye erişim ve kullanım konusunda eksik kaldığını düşünüyorum (A2)”, "Alt yapıyı yetersiz buluyorum. Internet yavaş kallyor. Çalışmalar için yeterli süre verilmediği için resmi olmayan "whatsapp" gibi programlar kullanmak zorunda kaldık (A5)"," Halen istenilen düzeyde değil. Teknoljik imkânlar etkileşimi daha fazla artttracak şekilde dizayn edilmeli. Bununla birlikte yine de teknolojik imkânlar bazen elde olmayan nedenlerden dolay dersin ahengini bozabiliyor (I20)", "Evinde telefon, tablet ya da bilgisayarı ile interneti olan öğrenci ve ögretmenler, rahatlıkla uzaktan eğitime dâhil olabilir. EBA yeterli alt yapıya sahip (O1)" ve" Teknik sorunlar oldukça fazla yaşaniyor. Orta yeterlikte bence (O7)" şeklinde ifade ettikleri görülmektedir.

$\mathrm{Bu}$ bulgulardan anlaşılacağı üzere öğretmenlerin yarısından fazlası alt yapının yeterli olduğunu, bazı öğretmenlerin alt yapıyı yetersiz bulduğu, bazılarının ise özellikle öğrencilerin mevcut imkânlarından kaynaklanan eksiklikler sebebiyle uzaktan eğitime erişim konusunda sıkıntı yaşadığ $\breve{s}_{1}$ sonucu elde edilmiştir. 


\section{Sizin ve Öğrencilerinizin Teknolojiye Erişim Konusunda Karşılaştığınız Problemleri Nasıl Değerlendirirsiniz? Sorusuna İlişkin Bulgular.}

Öğretmenlerin kendilerinin ve öğrencilerinin teknolojiye erişim konusunda karşılaştığ problemlere ilişkin görüşlere Tablo 5 'te yer verilmiştir.

$\mathrm{Bu}$ soruya ilişkin öğretmenlerden alınan görüşlere dayanarak 4 tema oluşturulmuştur. "Alt yapı yeterlik durumu" temasında yetersiz (f:6), yeterli (f:2), Eğitim Bilişim Ağına erişimde sorun yaşanması (f:1) olmak üzere 3 adet kod belirlenmiştir. "Öğrencilerin teknolojiye erişim durumu" temasında donanımsal yetersizlik (f:13), İnternet aboneliğinin ya da yeterli internet paketinin olmaması (f:18), öğrencilerin bireysel farklılıkları, gelişimleri sebebiyle erișim sorunu yașaması (f:4), Öğrencilerin isteksiz ve motivasyonlarının düşük olması (f:1) olmak üzere 4 kod belirlenmiştir. "Öğretmenlerin teknolojiye ilişkin öz yeterlikleri" temasında yetersiz (f:2) 1 kod belirlenmiştir. "Velilerden kaynaklanan teknolojiye erişim sorunları" temasında velilerin teknolojik bilgi eksikliği (f:5), velilerin ilgisiz olması (f:1) olmak üzere 2 kod oluşturulmuştur.

Oluşturulan kodlar incelendiğinde; 6 öğretmen alt yapının yetersiz olduğu, 2 öğretmen yeterli olduğu 1 öğretmen ise Eğitim Bilişim Ağına erişimde sorun yaşandığını; 13 öğretmen öğrencilerin teknolojiye erişimi konusunda donanımsal açıdan yetersizliklerinin olduğunu, 18 öğretmen internet aboneliği ya da yeterli internet paketlerinin olmadığını, 4 öğretmen öğrencilerin bireysel gelişimleri ve farklılıkları sebebiyle erişim sorunu yaşadığını; 2 öğretmen öğretmenlerin teknolojik açıdan yetersiz olduğunu; 5 öğretmen velilerin teknolojik bilgi eksikliğinin olduğunu, 1 öğretmense velilerin ilgisizliği sebebiyle öğrencilerin uzaktan eğitime erişimde sorun yaşadığını belirtmiştir (Tablo5).

Bazı öğretmenler kendilerinin ve öğrencilerinin teknolojiye erişim konusunda karşılaşılan problemlere ilişkin; "Genellikle velilerin telefon veya internetlerinin bulunmaması ( A1)", "Bazı ögrencilerimin evinde internetininin olmamast, kendinden büyük abi ve ablalarının eba canl yayınlarına internetlerin harcanması dolayısıyla okul öncesine giden küçük kardeşlere sira gelmiyor maalesef (A7)", "Herhangi bir sorun yaşamadık (i4)", "Ekonomik koşullarin yetersizliği yüzünden internet altyapist olmayan aileler, sadece tek telefon ile internete girebilen ögrenci dolayısıla sadece akşam baba eve gelince eba ya girebilmektedir. Motivasyon düşüklüğü eba tv yi bile düzenli izlememe. Ilgisiz ailelerin intetnete giremiyoruz bahanesi (i10)", "Teknolojiye erişim konusunda öğrencilerin çoğu sıkıntı yaşamaktadır. Evinde bilgisayarı, interneti olmayan pek çok ögrenci var. Sadece telefon interneti ile canlı derslere katılamıyor çocuklar. Ancak yeterli donanımı olan ögrencilerim ile verimli bir süreç yaşamaktayız (O1)", "Ebaya giriş bazen sorun yaratıyor. Çocuklar için girişs sorunları daha fazlaydı (Ö2)" ve "Ă̆ır düzeyde yetersizliği olan ögrenciler olmaları nedeniyle teknoloji ile uzaktan eğitim sürecine katılımları çok sinırlı ve veli desteği belirleyici olmuştur (Ö3) " görüşlerini belirtmişlerdir. 
Tablo 5: Öğrencilerin ve Öğretmenlerin Teknolojiye Erişim Konusunda Karşılaştıkları Problemlere İlişkin Veriler

\begin{tabular}{|c|c|c|c|c|c|c|c|}
\hline & Temalar & Kodlar & $\begin{array}{l}\text { Anasınıfi } \\
\text { Öğrt. (f) }\end{array}$ & $\begin{array}{l}\text { İllkokul } \\
\text { Öğgrt. (f) }\end{array}$ & $\begin{array}{l}\text { Ortaokul } \\
\text { Öğrt. (f) }\end{array}$ & $\begin{array}{l}\text { Özel Eğitim } \\
\text { Öğrt. (f) }\end{array}$ & Toplam (f) \\
\hline \multirow{3}{*}{1.} & \multirow{3}{*}{$\begin{array}{l}\text { Alt yap1 } \\
\text { yeterlik } \\
\text { durumu }\end{array}$} & 1-Yetersiz & $\begin{array}{l}\mathrm{A} 2, \mathrm{~A} 3, \dot{\mathrm{I}} 3 / \\
(3)\end{array}$ & & $\begin{array}{l}\text { O3, O8, } \\
\text { O9/ (3) }\end{array}$ & & 6 \\
\hline & & 2-Yeterli & & $\begin{array}{l}\mathrm{I} 4, \dot{\mathrm{I}} 15 / \\
(2)\end{array}$ & & & 2 \\
\hline & & $\begin{array}{l}\text { 3- Eğitim Bilişim } \\
\text { Ağına erişimde } \\
\text { sorun yaşanması }\end{array}$ & & & & Ö2/ (1) & 1 \\
\hline \multirow{4}{*}{2.} & \multirow{4}{*}{$\begin{array}{l}\text { Öğrencilerin } \\
\text { teknolojiye } \\
\text { erişim } \\
\text { durumu }\end{array}$} & $\begin{array}{l}\text { 1-Donanımsal } \\
\text { yetersizlik }\end{array}$ & $\begin{array}{l}\text { A1, A2, } \\
\text { A3, A5, } \\
\text { A7, A9/ } \\
\text { (6) }\end{array}$ & 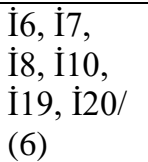 & $\mathrm{O} 1 /(1)$ & & 13 \\
\hline & & $\begin{array}{l}\text { 2-İnternet } \\
\text { aboneliğinin ya } \\
\text { da yeterli internet } \\
\text { paketinin } \\
\text { olmamas1 }\end{array}$ & $\begin{array}{l}\text { A1, A2, } \\
\text { A4, A5, } \\
\text { A7, A8, } \\
\text { A9/ (7) }\end{array}$ & $\begin{array}{l}\text { İ3, İ6, } \\
\text { İ7, İ8, } \\
\text { İ İ10, } \\
\text { İ16, ̇̇19, } \\
\text { İ20/ (9) }\end{array}$ & $\begin{array}{l}\mathrm{O} 1, \mathrm{O} 4 / \\
(2)\end{array}$ & & 18 \\
\hline & & $\begin{array}{l}\text { 3-Öğrencilerin } \\
\text { bireysel } \\
\text { farklılıkları, } \\
\text { gelişimleri } \\
\text { sebebiyle erişim } \\
\text { sorunu yaşaması }\end{array}$ & $\mathrm{A} 5 /(1)$ & & & $\begin{array}{l}\text { Ö3, Ö4, Ö5/ } \\
\text { (3) }\end{array}$ & 4 \\
\hline & & $\begin{array}{l}\text { 4-Öğrencilerin } \\
\text { isteksiz ve } \\
\text { motivasyonlarının } \\
\text { düşük olması }\end{array}$ & & & & Ö1/ (1) & 1 \\
\hline 3. & $\begin{array}{l}\text { Öğretmenlerin } \\
\text { teknolojiye } \\
\text { ilişkin öz } \\
\text { yeterlikleri }\end{array}$ & $1-$ Yetersiz & $\begin{array}{l}\text { A6, A8/ } \\
\text { (2) }\end{array}$ & & & & 2 \\
\hline \multirow[t]{2}{*}{4.} & \multirow{2}{*}{$\begin{array}{c}\text { Velilerden } \\
\text { kaynaklanan } \\
\text { teknolojiye } \\
\text { erişim } \\
\text { sorunlar1 }\end{array}$} & $\begin{array}{l}\text { 1-Velilerin } \\
\text { teknolojik bilgi } \\
\text { eksikliği }\end{array}$ & $\begin{array}{l}\text { A2,A3, } \\
\text { A5, A6/ } \\
\text { (4) }\end{array}$ & İ16/ (1) & & & 5 \\
\hline & & $\begin{array}{l}\text { 2-Velilerin ilgisiz } \\
\text { olmas1 }\end{array}$ & & İ10/ (1) & & & 1 \\
\hline
\end{tabular}

Bu bulgular 1şığında, öğretmenlerin uzaktan eğitime erişim konusunda en fazla problem yaşanan durumların, öğrencilerin ineternetlerinin olmaması, donanımsal araçlarının yetersizliği, velilerin teknolojik bilgi eksikliği konularında yoğunlaşttğı, bazı öğretmenlerin öğrencilerinin bireysel özellikleri sebebiyle uzaktan eğitime erişim konusunda sıkıntı yaşadıkları, bazı ögretmenlerin ise alt yapıdan kaynaklanan sorunlar olduğunu belirttikleri anlaşılmaktadır.

Öğrencilerinizin Ders İşleme Sırasındaki Motivasyon ve Derse Katılım Durumlarını Nasıl Değerlendirirsiniz? Sorusuna İlişkin Bulgular.

Öğretmenlerin, öğrencilerinin ders işleme sırasındaki motivasyon ve derse katılım durumlarına ilişkin görüşleri Tablo 6'da belirtilmiştir.

Bu soruya ilişkin görüşler incelendiğinde 2 tema ortaya çıkmaktadır. "Öğrenci motivasyon durumu" temasında yüksek düzeyde (f:5), orta düzeyde (f:3), düşük düzeyde (f:12), bireysel farklılıkların etkisi (f:4), dikkat sürelerinin kısa olması (f:6) olmak üzere 5 kod belirlenmiştir. 
"Uzaktan eğitim ve derse katılım” temasında yüksek düzeyde (f:9), orta düzeyde (f:6), düşük düzeyde (f:14) olmak üzere 3 kod oluşturulmuştur (Tablo 6).

Oluşturulan kodlar incelendiğinde 5 öğretmen öğrencilerin motivasyonlarının yüksek olduğunu, 3 öğretmen orta düzeyde, 12 öğretmen ise motivasyonlarının düşük olduğunu, 4 öğretmen motivasyon konusunda bireysel farkl1lıklar olduğunu, 6 öğretmen is öğrencilerin dikkat sürelerinin kısa olduğunu; uzaktan eğitim ve derse katılımın 9 öğretmen yüksek düzeyde, 6 öğretmen orta düzeyde, 14 öğretmen ise düşük düzeyde gerçekleştiğini belirtmiştir (Tablo 6).

Tablo 6: Öğrencilerin Motivasyon ve Derse Katılım Durumlarına İlişkin Veriler

\begin{tabular}{|c|c|c|c|c|c|c|c|}
\hline & Temalar & Kodlar & $\begin{array}{l}\text { Anasınıfi } \\
\text { Öğrt. (f) }\end{array}$ & $\begin{array}{l}\text { İlkokul } \\
\text { Öğrt. (f) }\end{array}$ & $\begin{array}{l}\text { Ortaokul } \\
\text { Öğrt. (f) }\end{array}$ & $\begin{array}{l}\text { Özel Eğitim } \\
\text { Öğrt. (f) }\end{array}$ & Toplam (f) \\
\hline \multirow{5}{*}{1.} & \multirow{5}{*}{$\begin{array}{c}\text { Öğrenci } \\
\text { motivasyon } \\
\text { durumu }\end{array}$} & $\begin{array}{l}\text { 1-Yüksek } \\
\text { düzeyde }\end{array}$ & $\begin{array}{l}\text { A3, A7, A8/ } \\
(3)\end{array}$ & $\begin{array}{l}\text { İ11, İ17 } \\
(2)\end{array}$ & & & 5 \\
\hline & & 2-Orta düzeyde & & $\begin{array}{l}\dot{\mathrm{I}} 2, \dot{\mathrm{I}} 4, \\
\dot{\mathrm{I}} 10 /(3)\end{array}$ & & & 3 \\
\hline & & 3-Düşük düzeyde & $\mathrm{A} 1, \mathrm{~A} 6 /(2)$ & $\begin{array}{l}\dot{\mathrm{I}} 5, \mathrm{I} 9, \\
\dot{\mathrm{I}} 14, \mathrm{I} 15 / \\
(4)\end{array}$ & $\begin{array}{l}\text { O3, O8, } \\
\text { O9, O10/ } \\
(4)\end{array}$ & Ö1, Ö2/ (2) & 12 \\
\hline & & $\begin{array}{l}\text { 4-Bireysel } \\
\text { farklılıkların } \\
\text { etkisi }\end{array}$ & A2/ (1) & İ8/ (1) & $\begin{array}{l}\mathrm{O} 1, \mathrm{O} 2 / \\
(2)\end{array}$ & & 4 \\
\hline & & $\begin{array}{l}\text { 5- Dikkat } \\
\text { sürelerinin k1sa } \\
\text { olmas1 }\end{array}$ & $\begin{array}{l}\text { A1, A6, A7, } \\
\text { A9/ (4) }\end{array}$ & $\dot{\mathrm{I}} 3 /(1)$ & & Ö5/ (1) & 6 \\
\hline \multirow{3}{*}{2.} & \multirow{3}{*}{$\begin{array}{l}\text { Uzaktan } \\
\text { eğitim ve } \\
\text { derse } \\
\text { katılım }\end{array}$} & $\begin{array}{l}\text { 1-Yüksek } \\
\text { düzeyde }\end{array}$ & $\begin{array}{l}\mathrm{A} 3, \mathrm{~A} 4, \mathrm{~A} 8 / \\
(3)\end{array}$ & $\begin{array}{l}\dot{\mathrm{I}} 11, \dot{\mathrm{I}} 12, \\
\dot{\mathrm{I}} 13, \mathrm{I} 20 / \\
(4)\end{array}$ & $\begin{array}{l}\mathrm{O} 1, \mathrm{O} 4 / \\
(2)\end{array}$ & & 9 \\
\hline & & 2-Orta düzeyde & & $\begin{array}{l}\dot{\mathrm{I}} 2, \dot{\mathrm{I}} 4, \\
\dot{\mathrm{I}} 10, \mathrm{I} 19 / \\
(4)\end{array}$ & $\begin{array}{l}\text { O6, O7/ } \\
\text { (2) }\end{array}$ & & 6 \\
\hline & & 3-Düşük düzeyde & $\begin{array}{l}\mathrm{A} 2, \mathrm{~A} 6, \mathrm{~A} 9 / \\
(3)\end{array}$ & $\begin{array}{l}\dot{\mathrm{I}} 5, \dot{\mathrm{I}} 6, \\
\dot{\mathrm{I}} 14 /(3)\end{array}$ & $\begin{array}{l}\text { O3, O5, } \\
\text { O10/ (3) }\end{array}$ & $\begin{array}{l}\text { Ö1, Ö2, } \\
\text { Ö3, Ö4, } \\
\text { Ö5/ (5) }\end{array}$ & 14 \\
\hline
\end{tabular}

Öğretmenlerin, öğrencilerinin ders işleme sırasındaki motivasyon ve derse katılım durumlarına ilişkin yazdıkları incelendiğinde "Çocuklar bir süre sonra sıkllıyor ve dikkatleri dă̆llyyor (A6)", "Dikkat süreleri zaten kısa olan çocuklara uzaktan eğitimle bir şeyler yaptırmaya çalışmak çok zor oluyor (A9)", "Yüz yüze eğitim kadar etkili bir sonuç görülmüyor (İ7)", "Sinıfin yarıdan fazlasının motivasyonu düşük (İ15)", "Açıkçası çalışkan ve sorumluluk sahibi ögrencilerin motivasyonları çok yüksek. Gerek whatsapptan gerekse EBA üzerinden verilen tüm derslere katılım sağlayabiliyorlar. Ödevlerini yapıyor, öğretmene dönüt verebiliyorlar. Bunda velinin ilgisinin de etkili olduğunu düşünüyorum (O1)”, "Canlı derslere katılım düşük fakat katılan öğrenciler derse odaklanıp dinleyebiliyor (O5)" ve "Özel eğitim öğrencilerimiz için verimsiz olduğunu düşünüyorum (Ö4)” ş̧eklinde ifade ettikleri görülmektedir.

Öğretmenlerin görüşlerinden elde edilen bu bulgulara göre, öğretmenlerin çoğu uzaktan eğitim sürecinde, öğrencilerin motivasyonlarının düşük olduğu, bununla birlikte öğrencilerin derse katılım gösterdiği, öğrencilerin bireysel özellikleri sebebiyle derse katılım ve motivasyon durumlarının farklılık gösterdiği anlaşılmaktadır. 


\section{Velilerin Uzaktan Eğitim Sürecine Destek ve Katılım Durumlarını Nasıl Değerlendirirsiniz? Sorusuna İlişkin Bulgular.}

Öğretmenlerin, velilerin uzaktan eğitim sürecine destek ve katılım durumlarına ilişkin görüşlerine Tablo 7'de yer verilmiştir.

$\mathrm{Bu}$ soruya ilişkin görüşlerin 1 tema altında toplandığı görülmektedir. "Veli desteği”" temasında yeterli düzeyde (f:13), orta düzeyde yeterli (f:6), yetersiz (f:12), veli iş yoğunluğu sebebiyle yetersiz (f:4), internet paketlerinin yetersizliği sebebiyle yetersiz (f:1), velilerin uzaktan eğitime yönelik farkındalık düzeylerine göre farklılaşmakta (f:7), büyük çocuklara öncelik vermeleri sebebiyle küçük çocuklara daha az destek sağlanması (f:1) olmak üzere 7 adet kod oluşturulmuştur (Tablo 7).

Oluşturulan kodlar incelendiğinde uzaktan eğitim sürecinde veli desteği ile ilgili 13 öğretmen yeterli gördüğünü, 6 öğretmen orta düzeyde yeterli, 12 öğretmen yetersiz gördüğünü, 4 öğretmen velilerin iş yoğunlukları sebebiyle yeterli desteği sağlayamadığını, 1 öğretmen internet paketlerinin yetersizliği sebebiyle desteğin yetersiz kaldığını, 7 öğretmen velilerin uzaktan eğitime yönelik farkındalık düzeylerine göre farklılaşmakta olduğunu, 1 öğretmen ise büyük çocuklara öncelik vermeleri sebebiyle küçük çocuklara daha az destek sağlandığını belirtmiştir (Tablo7).

Tablo 7: Velilerin Uzaktan Eğitim Sürecine Destek ve Katılım Durumlarına İlişkin Veriler

\begin{tabular}{|c|c|c|c|c|c|c|c|}
\hline & Temalar & Kodlar & $\begin{array}{l}\text { Anasınıfi } \\
\text { Öğrt. (f) }\end{array}$ & $\begin{array}{l}\text { İlkokul } \\
\text { Öğrt. (f) }\end{array}$ & $\begin{array}{l}\text { Ortaokul } \\
\text { Öğrt. (f) }\end{array}$ & $\begin{array}{l}\text { Özel } \\
\text { Ĕgitim } \\
\text { Öğrt. (f) }\end{array}$ & Toplam (f) \\
\hline \multirow{7}{*}{1.} & \multirow{7}{*}{$\begin{array}{c}\text { Veli } \\
\text { desteği }\end{array}$} & 1-Yeterli & $\begin{array}{l}\text { A3, A8/ } \\
\text { (2) }\end{array}$ & $\begin{array}{l}\text { İ2, İ9, } \\
\dot{\mathrm{I}} 12, \dot{\mathrm{I}} 13, \\
\dot{\mathrm{I}} 17, \dot{\mathrm{I}} 18, \\
\text { İ19/ (7) }\end{array}$ & $\begin{array}{l}\mathrm{O} 3, \mathrm{O} 4 \\
\mathrm{O} 6, \mathrm{O} 7 \mathrm{I} \\
(4)\end{array}$ & & 13 \\
\hline & & 2-Orta düzeyde yeterli & A5/ (1) & $\begin{array}{l}\dot{\mathrm{I}} 11, \dot{\mathrm{I}} 14, \\
\text { İ15/ (3) }\end{array}$ & $\begin{array}{l}\text { O8, O9/ } \\
\text { (2) }\end{array}$ & & 6 \\
\hline & & 3-Yetersiz & $\mathrm{A} 1, \mathrm{~A} 6 /(2)$ & $\begin{array}{l}\dot{\mathrm{I}} 1, \dot{\mathrm{I}} 4, \dot{\mathrm{I}} 5, \\
\dot{\mathrm{I}} 6, \mathrm{I} 7 \\
\dot{\mathrm{I}} 16 /(6)\end{array}$ & $\begin{array}{l}\mathrm{O} 2, \mathrm{O} 5 / \\
\text { (2) }\end{array}$ & $\begin{array}{l}\text { Ö3, Ö5/ } \\
\text { (2) }\end{array}$ & 12 \\
\hline & & $\begin{array}{l}\text { 4- Velilerin iş } \\
\text { yoğunluğu sebebiyle } \\
\text { yetersiz }\end{array}$ & $\begin{array}{l}\text { A2, A4/ } \\
(2)\end{array}$ & & $\mathrm{O} 10 /(1)$ & Ö1/ (1) & 4 \\
\hline & & $\begin{array}{l}\text { 5- İnternet paketlerinin } \\
\text { yetersizliği sebebiyle } \\
\text { yetersiz }\end{array}$ & $\mathrm{A} 4 /(1)$ & & & & 1 \\
\hline & & $\begin{array}{l}\text { 6- Velilerin uzaktan } \\
\text { eğitime yönelik } \\
\text { farkındalık düzeylerine } \\
\text { göre farklılaşmakta }\end{array}$ & A9/ (1) & $\begin{array}{l}\dot{\mathrm{I}} 8, \dot{\mathrm{I}} 10, \\
\dot{\mathrm{I}} 15, \dot{\mathrm{I}} 19 / \\
(4)\end{array}$ & $\mathrm{O} 1 /(1)$ & Ö2/ (1) & 7 \\
\hline & & $\begin{array}{l}\text { 7-Büyük çocuklara } \\
\text { öncelik vermeleri } \\
\text { sebebiyle küçük } \\
\text { çocuklara daha az } \\
\text { destek sağlanması }\end{array}$ & A7/ (1) & & & & 1 \\
\hline
\end{tabular}

Uzaktan eğitim sürecinde velilerin destek ve katılım durumlarını ele alan öğretmenlerin yazdıkları incelendiğinde; "Velilerimizin yarısı sürece katılmakta ve desteklemekte diğer yarısı katılmamaktadır. Bu nedenle sinıfimın yarısı eğitimden faydalanamamaktadır (A5)", "Takip etmeye çalıştıkların fakat yeterli olamadıklarını düşünüyorum (İ)", "Olabildiğince öğretmene destek olarak yürütüyorlar (I13)”, "Destek konusunda fazlasıyla yük almış durumdalar, çok fazla sorumluluklart var, eğitim sürecinin ilgili velileri yorduğunu söyleyebilirim (O7)" ve "Velilerin 
bazıları ilgilenirken, bazılarına ulaşmak bile mümkün olamıyor (Ö2)" şeklinde ifadelerle durumu anlatmışlardır.

Konuya ilişkin bulgulara bakıldığında, öğretmenlerin çoğu velilerin büyük ölçüde uzaktan eğitim sürecine destek olduğunu, uzaktan eğitime ilişkin farkındalık, velilerin iş durumları gibi sebeplere bağlı olarak öğrencilerin uzaktan eğitim durumlarını takip ettikleri ve destekledikleri anlaşılmaktadır.

\section{Dezavantajlı Durumda Olan Öğrencilerinizin Uzaktan Eğitimden Yararlanma Süreçlerini Nasıl Değerlendirirsiniz? Sorusuna İlişkin Bulgular.}

Öğretmenlerin dezavantajlı durumda olan öğrencilerin uzaktan eğitimden yararlanma süreçlerine ilişkin görüşlerine Tablo 8'de yer verilmiştir.

$\mathrm{Bu}$ soruya ilişkin görüşler incelendiğinde 3 tema ortaya çıkmaktadır. "Öğrencilerin bireysel gelişim özelliklerine uygunluk ve yararlanabilme durumları" temasında yeterli (f:1), orta düzeyde yeterli (f:3), yetersiz (f:22) olmak üzere 3 kod belirlenmiştir. "Alt yapı ve içeriklerin uygunluğu" temasında yetersiz (f:3), internet paketi ve donanımsal araç yetersizliği (2) olmak üzere 2 kod belirlenmiştir. "Veli desteği" temasında velilerin ilgisizliği (f:3) olmak üzere 1 adet kod oluş̧urulmuştur.

Oluşturulan kodlar incelendiğinde dezavantajlı öğrencilerin uzaktan eğitimden yararlanabilmeleri konusunda 1 öğretmen yeterli düzeyde yararlanabildiğini, 3 öğretmen orta düzeyde yararlanabildiğini, 22 öğretmen ise yararlanabilme durumlarının yetersiz olduğunu, 3 öğretmen alt yapı ve içerik bakımından yetersiz olduğunu, 2 öğretmen, dezavantajlı öğrencilerin internet paketi ve donanımsal araç bakımından yetersiz kaldığını, 3 öğretmen ise veli desteğinin süreçte yetersiz olduğunu belirtmiştir (Tablo 8).

Tablo 8: Dezavantajlı Durumda Olan Öğrencilerin Uzaktan Eğitimden Yararlanma Süreçlerine

\begin{tabular}{|c|c|c|c|c|c|c|c|}
\hline \multicolumn{8}{|c|}{ İlişkin Veriler } \\
\hline & emalar & Kodlar & $\begin{array}{l}\text { Anasınıfi } \\
\text { Öğrt. (f) }\end{array}$ & $\begin{array}{l}\text { İlkokul } \\
\text { Öğrt. (f) }\end{array}$ & $\begin{array}{l}\text { Ortaokul } \\
\text { Ö̆ğrt. (f) }\end{array}$ & $\begin{array}{l}\text { Özel Eğitim } \\
\text { Öğrt. (f) }\end{array}$ & $\begin{array}{l}\text { Toplam } \\
\text { (f) }\end{array}$ \\
\hline \multirow{3}{*}{1.} & \multirow{3}{*}{$\begin{array}{l}\text { Öğrencilerin } \\
\text { Bireysel Gelişim } \\
\text { Özelliklerine } \\
\text { uygunluk ve } \\
\text { yararlanabilme } \\
\text { durumları }\end{array}$} & 1-Yeterli & $\mathrm{A} 6 /(1)$ & & & & 1 \\
\hline & & $\begin{array}{l}\text { 2-Orta } \\
\text { düzeyde } \\
\text { yeterli }\end{array}$ & & İ19/ (1) & $\begin{array}{l}\mathrm{O} 3, \mathrm{O} 6 / \\
(2)\end{array}$ & & 3 \\
\hline & & 3-Yetersiz & $\begin{array}{l}\text { A2, A5, } \\
\text { A9/ (3) }\end{array}$ & $\begin{array}{l}\mathrm{İ} 7, \text { İ17, İ20, } \\
\text { İ2, İ4, İ6, } \\
\text { İ8, İ9, İ11, } \\
\text { İ16/ (10) }\end{array}$ & $\begin{array}{l}\text { O5, O7, } \\
\text { O8, O9/ } \\
\text { (4) }\end{array}$ & $\begin{array}{l}\text { Ö1, Ö2, Ö3, } \\
\text { Ö4, Ö5/ (5) }\end{array}$ & 22 \\
\hline \multirow[b]{2}{*}{2.} & & 1-Yetersiz & $\mathrm{A} 2 /(1)$ & $\dot{\mathrm{I}} 5 /(1)$ & & & 3 \\
\hline & $\begin{array}{l}\text { Alt yapı ve } \\
\text { içeriklerin } \\
\text { uygunluğu }\end{array}$ & $\begin{array}{l}\text { 2-İnternet } \\
\text { paketi ve } \\
\text { donanımsal } \\
\text { araç } \\
\text { yetersizliği }\end{array}$ & A4/ (1) & İ14/ (1) & & & 2 \\
\hline 3. & Veli desteği & $\begin{array}{l}\text { 1-Velilerin } \\
\text { İlgisizliği }\end{array}$ & A8/ (1) & & O1/ (1) & Ö3/ (1) & 3 \\
\hline
\end{tabular}

Öğretmenlerin dezavantajlı durumda olan öğrencilerin uzaktan eğitimden yararlanma süreçlerine ilişkin görüşlerine bakıldığında; "Dezavantajlı olan bazı öğrencilerim okullara ara verildiğinden beri hiçbir etkinliğe katılamadı (A9)", "Büyük sılkıntı yaşıyorlar. Okulda birebirde bile zorluk yaşarken, bu şekilde çok verimsiz (I9)", "Bu süreçte de dezavantajl durumdalar bence, birebir eğitim kısmı gerçekleşmediği için pek verimli olduğunu düşünmüyorum (O7)" ve 
"Yararlanamıyor. Verimli geçmiyor. Onları derste tutabilmek dikkatlerini verdirebilmek çok zor (Ö2)" şeklinde ifadeler kullandıkları görülmektedir.

Elde edilen bu bulgular 1şığında, öğretmenlerin büyük çoğunluğu uzaktan eğitim sürecinde dezavantajlı durumda olan öğrencilerin yeterince eğitimden yararlanamadığı, uzaktan eğitimin bu grupta yer alan öğrencilere çok uygun olmadığı, öğrencilerin bireysel özellikleri nedeniyle kısıtlı bir ölçüde uzaktan eğitim imkânlarından yararlanabildikleri anlaşılmaktadır.

\section{Uzaktan Eğitim Sürecinde, Müfredatın Uygulanması ve Derslerin İşleniş Sürecini Nasıl Değerlendirirsiniz? Sorusuna İlişkin Bulgular.}

Öğretmenlerin uzaktan eğitim sürecinde, müfredatın uygulanması, derslerin işleniş sürecine ilişkin görüşlerine Tablo 9' da yer verilmiştir.

$\mathrm{Bu}$ soruya ilişkin görüşler incelendiğinde 1 tema altında toplandığı görülmektedir. "Müfredatın uygulanması" temasında, yeterince uygulandı (f:7), orta düzeyde uygulandı (f:6), müfredatın uygulanışı açısından yetersiz (f:15), müfredatı uygulamak için yeterli sürenin olmaması (f:2), internet alt yapı yetersizliği (f:1), müfredatın uzaktan eğitimle uygulama yapmaya imkân vermemesi (f:2) olmak üzere 6 kod oluşturulmuştur.

Oluşturulan kodlar incelendiğinde uzaktan eğitim sürecinde müfredatın uygulanması ve derslerin işlenmesi konusunda 7 öğretmen yeterince uygulanabildiğini, 6 öğretmen orta düzeyde uygulanabildiğini, 15 öğretmen ise yeterince uygulanamadığını, 2 öğretmen müfredatı uygulamak için yeterli sürenin olmadığını, 1 öğretmen internet alt yapısının yetersizliği sebebiyle uygulanamadığını, 2 öğretmen müfredatın uzaktan eğitimle uygulama yapmaya imkan vermediğini belirtmiştir (Tablo 9).

Tablo 9: Uzaktan Eğitim Sürecinde, Müfredatın Uygulanması ve Derslerin İşleniş Sürecine İlişkin

\begin{tabular}{|c|c|c|c|c|c|c|c|}
\hline \multicolumn{8}{|c|}{ Veriler } \\
\hline & Temalar & Kodlar & $\begin{array}{l}\text { Anasınıfı } \\
\text { Öğrt. (f) }\end{array}$ & $\begin{array}{l}\text { İlkokul } \\
\text { Öğrt. (f) }\end{array}$ & $\begin{array}{l}\text { Ortaokul } \\
\text { Ögrtt. (f) }\end{array}$ & $\begin{array}{l}\text { Özel } \\
\text { Eğitim } \\
\text { Öğrt. (f) }\end{array}$ & $\begin{array}{l}\text { Toplam } \\
\text { (f) }\end{array}$ \\
\hline \multirow{6}{*}{1.} & \multirow{6}{*}{$\begin{array}{l}\text { Müfredatın } \\
\text { uygulanmas1 }\end{array}$} & $\begin{array}{l}\text { 1- Yeterince } \\
\text { uyguland1 }\end{array}$ & A4/ (1) & $\dot{\mathrm{I}} 2, \dot{\mathrm{I}} 12 /(2)$ & $\begin{array}{l}\text { O2, O4, O5, } \\
\text { O6/ (4) }\end{array}$ & & 7 \\
\hline & & $\begin{array}{l}\text { 2- orta düzeyde } \\
\text { uyguland } 1\end{array}$ & $\mathrm{~A} 2, \mathrm{~A} 3 /(2)$ & $\begin{array}{l}\dot{\mathrm{I}} 11, \dot{\mathrm{I}} 20 / \\
\text { (2) }\end{array}$ & O8, O9/ (2) & & 6 \\
\hline & & $\begin{array}{l}\text { 3-Müfredatın } \\
\text { uygulanışı } \\
\text { açısından } \\
\text { yetersiz }\end{array}$ & $\begin{array}{l}\text { A1, A5, A6/ } \\
\text { (3) }\end{array}$ & $\begin{array}{l}\text { İ3, İ4, İ5, } \\
\text { İ6, İ9, İ18, } \\
\text { İ19/ (7) }\end{array}$ & O7/ (1) & $\begin{array}{l}\text { Ö1, Ö3, } \\
\text { Ö4, Ö5/ } \\
\text { (4) }\end{array}$ & 15 \\
\hline & & $\begin{array}{l}\text { 4- Müfredatı } \\
\text { uygulamak için } \\
\text { yeterli sürenin } \\
\text { olmaması }\end{array}$ & & İ17/ (1) & $\mathrm{O} 1 /(1)$ & & 2 \\
\hline & & $\begin{array}{l}\text { 5- İnternet alt } \\
\text { yap1 yetersizliği }\end{array}$ & A9/ (1) & & & & 1 \\
\hline & & $\begin{array}{l}\text { 6-Müfredatın } \\
\text { uzaktan eğitimle } \\
\text { uygulama } \\
\text { yapmaya imkân } \\
\text { vermemesi }\end{array}$ & & $\begin{array}{l}\mathrm{İ} 10, \dot{\mathrm{I}} 16 / \\
(2)\end{array}$ & & & 2 \\
\hline
\end{tabular}

Uzaktan eğitimin uygulanması sürecinde müfredatın uygulanması ve derslerin işlenişine ilişkin öğretmenlerin görüşlerini incelendiğinde; "Müfredatın uzaktan eğitim yoluyla kazandırılması mümkün gözükmemektedir. Çocukların kazanımları kazanıp kazanmadıklarını gözlemlemek mümkün olmamaktadır (A5)", "Müfredatı yeteri kadar uygulayamıyoruz (I3)", 
"Uzaktan eğitim sürecinde müfredat ve derslerin uygulanması esnasinda eksiklikler oluyor. Teknolojinin sunduğu imkânlar sayesinde dersler yapillyor fakat bir tarafi eksik gibi oluyor. Sanal ortam sınıf ortamını tutmuyor (II18)", "Eba tv daha belirleyici, ögrencilerin müfredatı takibini kolaylaştırmakta (O3)", "Ben düzenli bir şekilde uyguluyorum. Tabiki yüz yüze eğitim daha etkili (O4)" ve "Aile desteği ile kusmen eğitsel ihtiyaçları karşılanmakta olup uzaktan eğitim kapsamında yeterli düzeyde değildir (Ö4)" görüşlerini dile getirdikleri görülmektedir.

$\mathrm{Bu}$ bulgulardandan da anlaşılacağı üzere öğretmenlerin çoğu müfredatın tam anlamıyla uygulanmadığını, bazı öğretmenlerin ise büyük ölçüde müfredatı uyguladığını ve dersleri işleyebildiğini bununla birlikte bazı derslerin ve kazanımların uzaktan eğitimle uygulama yapmaya imkan vermediği görülmektedir.

\section{Sizce Uzaktan Eğitim-Öğretim Faaliyetlerinin Olumlu ve Olumsuz Yanları Nelerdir? Sorusuna İlişkin Bulgular.}

Öğretmenlerin uzaktan eğitim-öğretim faaliyetlerinin olumlu ve olumsuz yanlarına ilişkin görüşlerine Tablo 10'da yer verilmiştir.

Bu soruya ilişkin görüşler incelendiğinde 2 tema ortaya çıkmaktadır. "Olumsuz yanlar" temasında yeterli iletişim, etkileşim ve geri dönüt sağlanamaması (f:14), öğrencilerin tümüne erişim sağlanamaması (f:9), öğrencilerin derse katılım ve motivasyonlarının düşük olması (f:7), öğrencilerde teknolojik bağımlılık ve zararlı etkilere yol açması (f:2), teknolojik alt yap1 yetersizliği (f:4), yeterli düzeyde teknolojik bilgi ve teknolojik farkındalık gerektirmesi (f:1), öğretmenlerin iş yükünün artması (f:3), öğrencilerin erişimi için yeterli internet paketi ve teknolojik donanım gerektirmesi, öğrencilerin yeterli imkânlarının olmaması (f:5), öğretmen - veli iletişimini olumsuz yönde etkilemesi (f:1), ders saatlerinin yetersizliği (f:3), bireyselleştirilmiş eğitime uygun olmaması (f:3), Öğrencilerin uzaktan eğitime katılımlarının zorunlu olmaması (f:1) olmak üzere 12 kod belirlenmiştir. "Olumlu yanlar" temasında ise zamandan ve mekândan tasarruf sağlanması (f:4), teknolojik okuryazarlık yeterlilik düzeyini artırması (f:4), yaygın hastalık döneminde öğrencilerle iletişim ve ders tekrarı imkânı sağlaması (f:10), veli desteğini artırmış olması (f:1), zenginleştirilmiş eğitim içeriklerine ulaşım imkânı sağlaması (f:1) olmak üzere 5 kod oluşturulmuştur (Tablo 10).

Oluşturulan kodlar incelendiğinde uzaktan eğitimin, 14 öğretmen yeterli iletişim, etkileşim ve geri dönüt sağlanamaması, 9 öğretmen öğrencilerin tümüne erişim sağlanamaması, 7 öğretmen, öğrencilerin derse katılım ve motivasyonlarının düşük olması, 2 öğretmen, öğrencilerde teknolojik bağımlılık ve zararlı etkilere yol açması, 4 öğretmen teknolojik alt yapı yetersizliği, 1 öğretmen yeterli düzeyde teknolojik bilgi ve teknolojik farkındalık gerektirmesi, 3 öğretmen öğretmenlerin iş yükünün artması, 5 öğretmen öğrencilerin erişimi için yeterli internet paketi ve teknolojik donanım gerektirmesi ve öğrencilerin yeterli imkânlarının olmaması, 1 öğretmen velilerle iletişimi olumsuz yönde etkilemesi, 1 öğretmen ders saatlerinin yetersizliği, 3 öğretmen bireyselleştirilmiş eğitime uygun olmaması, 1 öğretmen öğrencilerin uzaktan eğitime katılımlarının zorunlu olmaması sebebiyle olumsuz yanlarının bulunduğunu ifade etmektedir (Tablo 10).

4 öğretmen zamandan ve mekândan tasarruf sağlanması, 4 öğretmen teknolojik okuryazarlık yeterlilik düzeyini artırması, 10 öğretmen yaygın hastalık döneminde öğrencilerle iletişim ve ders tekrarı imkânı sağlaması, 1 öğretmen veli desteğini artırmış olması, 1 öğretmen zenginleştirilmiş eğitim içeriklerine ulaşım imkânı sağlaması açısından olumlu yanlarının olduğunu belirtmiştir (Tablo 10).

Tablo 10: Uzaktan Eğitim Sürecinin Olumlu ve Olumsuz Yanlarına İlişkin Veriler

\begin{tabular}{|c|c|c|c|c|c|c|}
\hline Temalar & Kodlar & $\begin{array}{l}\text { Anasınıfi } \\
\text { Öğrt. (f) }\end{array}$ & $\begin{array}{l}\text { İlkokul } \\
\text { Öğrt. (f) }\end{array}$ & $\begin{array}{l}\text { Ortaokul } \\
\text { Öğrt. (f) }\end{array}$ & $\begin{array}{l}\text { Özel } \\
\text { Eğitim } \\
\text { Öğrt. (f) }\end{array}$ & $\begin{array}{l}\text { Toplam } \\
\text { (f) }\end{array}$ \\
\hline Olumsuz & 1- Yeterli iletişim, & $\mathrm{A} 2, \mathrm{~A} 3$, & İ5, İ15/ & $\mathrm{O} 2, \mathrm{O} 4$, & Ö1, Ö2, & 14 \\
\hline
\end{tabular}




\begin{tabular}{|c|c|c|c|c|c|c|c|}
\hline & \multirow[t]{12}{*}{ yanlar } & $\begin{array}{l}\text { etkileşim ve geri dönüt } \\
\text { sağlanamaması }\end{array}$ & $\begin{array}{l}\text { A4, A5, } \\
\text { A8/ (5) }\end{array}$ & (2) & $\begin{array}{l}\mathrm{O} 5, \mathrm{O} 7 \mathrm{I} \\
(4)\end{array}$ & Ö3/ (3) & \\
\hline & & $\begin{array}{l}\text { 2- Öğrencilerin tümüne } \\
\text { erişim sağlanamaması }\end{array}$ & $\begin{array}{l}\mathrm{A} 2, \mathrm{~A} 6 / \\
(2)\end{array}$ & $\begin{array}{l}\dot{\mathrm{I}} 5, \dot{\mathrm{I}} 8 \\
\dot{\mathrm{I}} 11, \dot{\mathrm{I}} 12 \\
\dot{\mathrm{I}} 13 /(5)\end{array}$ & O1/ (1) & Ö3/ (1) & 9 \\
\hline & & $\begin{array}{l}\text { 3- Öğrencilerin derse } \\
\text { katılım ve } \\
\text { motivasyonlarının düşük } \\
\text { olması }\end{array}$ & $\begin{array}{l}\text { A5, A7/ } \\
\text { (2) }\end{array}$ & $\begin{array}{l}\dot{\mathrm{I}} 1, \dot{\mathrm{I}} 2, \dot{\mathrm{I}} 9 / \\
(3)\end{array}$ & & $\begin{array}{l}\text { Ö4, Ö5/ } \\
\text { (2) }\end{array}$ & 7 \\
\hline & & $\begin{array}{l}\text { 4- Öğrencilerde } \\
\text { teknolojik bağımlılık ve } \\
\text { zararlı etkilere yol açması }\end{array}$ & A5/ (1) & İ19/ (1) & & & 2 \\
\hline & & $\begin{array}{l}5-\text { Teknolojik alt yap1 } \\
\text { yetersizliği }\end{array}$ & & $\begin{array}{l}\text { İ6, İ8, } \\
\text { İ18/ (3) }\end{array}$ & O8/ (1) & & 4 \\
\hline & & $\begin{array}{l}\text { 6- Yeterli düzeyde } \\
\text { teknolojik bilgi ve } \\
\text { teknolojik farkındalık } \\
\text { gerektirmesi }\end{array}$ & & İ7/ (1) & & & 1 \\
\hline & & $\begin{array}{l}\text { 7- Öğretmenlerin iş } \\
\text { yükünün artması }\end{array}$ & & $\begin{array}{l}\text { İ8, İ12, } \\
\text { İ13/ (3) }\end{array}$ & & & 3 \\
\hline & & $\begin{array}{l}\text { 8- Öğrencilerin erişimi } \\
\text { için yeterli internet paketi } \\
\text { ve teknolojik donanım } \\
\text { gerektirmesi, öğrencilerin } \\
\text { yeterli imkânlarının } \\
\text { olmaması }\end{array}$ & A9/ (1) & $\begin{array}{l}\text { İ19, İ20 } \\
\text { İ12, İ13/ } \\
\text { (4) }\end{array}$ & & & 5 \\
\hline & & $\begin{array}{l}\text { 9- Öğretmen - veli } \\
\text { iletişimini olumsuz yönde } \\
\text { etkilemesi }\end{array}$ & & İ12/ (1) & & & 1 \\
\hline & & $\begin{array}{l}\text { 10- Ders saatlerinin } \\
\text { yetersizliği }\end{array}$ & & İ17/ (1) & & & 1 \\
\hline & & $\begin{array}{l}\text { 11- Bireyselleştirilmiş } \\
\text { eğitime uygun olmaması }\end{array}$ & & İ20/ (1) & & $\begin{array}{l}\text { Ö3, Ö5/ } \\
(2)\end{array}$ & 3 \\
\hline & & $\begin{array}{l}\text { 12- Öğrencilerin uzaktan } \\
\text { eğitime katılımlarının } \\
\text { zorunlu olmaması }\end{array}$ & & & O3/ (1) & & 1 \\
\hline & \multirow{5}{*}{$\begin{array}{l}\text { Olumlu } \\
\text { yanlar }\end{array}$} & $\begin{array}{l}\text { 1- Zamandan ve } \\
\text { mekândan tasarruf } \\
\text { sağlanması }\end{array}$ & $\begin{array}{l}\text { A1, A3, } \\
\text { A6/ (3) }\end{array}$ & İ18/ (1) & & & 4 \\
\hline & & $\begin{array}{l}\text { 2- Teknolojik } \\
\text { okuryazarlık yeterlilik } \\
\text { düzeyini artırması }\end{array}$ & A2/ (1) & $\begin{array}{l}\dot{\mathrm{I}} 12, \dot{\mathrm{I}} 13, \\
\dot{\mathrm{I}} 20 /(3)\end{array}$ & & & 4 \\
\hline & & $\begin{array}{l}\text { 3- Yaygın hastalık } \\
\text { döneminde öğrencilerle } \\
\text { iletişim ve ders tekrarı } \\
\text { imkânı sağlaması }\end{array}$ & $\begin{array}{l}\text { A5, A7/ } \\
\text { (2) }\end{array}$ & $\begin{array}{l}\dot{\mathrm{I}} 3, \dot{\mathrm{I}} 5, \dot{\mathrm{I}} 6, \\
\dot{\mathrm{I}} 19 /(4)\end{array}$ & $\begin{array}{l}\mathrm{O} 1, \mathrm{O} 2 \\
\mathrm{O} 8 /(3)\end{array}$ & Ö1/ (1) & 10 \\
\hline & & $\begin{array}{l}\text { 4- Veli desteğini artırmış } \\
\text { olması }\end{array}$ & A8/ (1) & & & & 1 \\
\hline & & $\begin{array}{l}\text { 5- Zenginleştirilmiş } \\
\text { eğitim içeriklerine ulaşım } \\
\text { imkânı sağlaması }\end{array}$ & & İ10/ (1) & & & 1 \\
\hline
\end{tabular}

Öğretmenlerin uzaktan eğitim-öğretim faaliyetlerinin olumlu ve olumsuz yanlarına ilişkin yazdıklarına bakıldığında; "Olumlu yanı zamandan mekândan tasarruf. Olumsuz yanı ulaşım eksikliği, etkileşim eksikliği, sosyal alan eksikliği (A3)", "Olumlu yanı pandemi sürecinde 
öğrencilerin okuldan kopmamasını ve kazanımların tekrarını sağlaması. Olumsuz yanı yaş grubu nedeniyle veliye bağımlılık, motivasyon düşüklügü, dönüt sağlanmasında güçlük, eğitimsel süreçlerin değerlendirilmesinde güçlükler, eğitimin sosyal beceri kazandirma yönünün desteklenememesi (A5)", "Uzaktan eğitim, destekleyici olmalı. Yüz yüze eğitime alternatif değil (I16)", "Teknoloji bă̆gmlılı̆̆ ve hareketsizlik. Olumlu tarafi okuldan bağ koparmayı engelliyor (I19)", "Olumlu yanlart: Yaşanan tehlikeli durumdan uzakta, eğitime evimizden devam edebilmek çok güzel. Uzaktan eğitime geçilmeseydi okullardaki kalabalık nüfus yüzünden corona virüsün yayılması daha çok olacaktı. Olumsuz yanları: Tüm ögrenciler uzaktan eğitime dâhil olamıyor. Öğrencilerin çoğunda uyku düzeni bozuldu. Ramazan ayı ve sahur dolayıslyla ögrencilerin çoğu sabaha kadar uyumayıp uykusuz kaldığ için sabahlarl yapılan EBA canlı derslere katılamıyor. Bir de maalesef birçok ögretmen ögrenciler ile irtibata geçmiyor. Kimi ögretmenler ilk günden itibaren çocukları boş bırakmadı kimisi de hiç ilgilenmedi (O1)" ve "Özel gereksinimli olan öğrenciler için çok uygun değil dikkat süreleri çok kısa (Ö5) şeklinde ifadelerle izah ettikleri görülmektedir.

$\mathrm{Bu}$ bulgular ışığında, öğretmenlerin çoğu uzaktan eğitimle yeterli iletişim, etkileşim ve geri dönüt sağlanamaması, öğrencilerin tümüne erişim sağlanamaması, bazı öğretmenler öğrencilerin motivasyonlarının düşük olması gibi olumsuz yanlarını; bununla birlikte bazıları da uzaktan eğitimin yaygın hastalık döneminde eğitim fitsatları ve imkânı sunması, zamandan ve mekândan tasarruf sağlaması gibi olumlu yanlarını ortaya koymuşlardır.

\section{Uzaktan Eğitim Sürecinde Evde Kalmak Zorunda Olan Öğrencilerinizin (Sosyal, Fiziksel Ve Psikolojik) Durumlarını Olumlu/Olumsuz Yönleriyle Nasıl Değerlendirirsiniz? Sorusuna İlişsin Bulgular.}

Öğretmenlerin uzaktan eğitim sürecinde evde kalmak zorunda olan öğrencilerin (sosyal, fiziksel ve psikolojik) durumlarının olumlu/olumsuz yönlerine ilişkin görüşlerine Tablo 11'de yer verilmiştir.

$\mathrm{Bu}$ soruya ilişkin olarak 3 tema oluşturulmuştur. "Psikolojik etkiler" temasında öğrencilerin olumsuz yönde etkilenmesi (f:18), teknolojik bağımlılığa yol açması (f:1), derse ilişkin ilginin ve motivasyonun düşmesi (f:19), temizlik ve hijyen takıntısı oluşması (f:1) olmak üzere 4 kod bulunmaktadır. "Sosyal etkiler" temasında Sosyal iletişim, etkileşim becerilerini geliştirme fırsatlarının kısıtlı olması (f:12), aileleri ile daha çok vakit geçirme imkânının olması (f:8), kişisel gelişim için yeterince zaman olması (f:1) olmak üzere 3 kod bulunmaktadır. "Fiziksel etkiler" temasında ise sağlık açısından olumsuz etkilerinin olması (f:4), hareketsiz yaşamları ve kilo problemlerinin olması (f:10), temizlik ve hijyen takıntısı sebebi ile ellerde alerji oluşması (f:1) olmak üzere 3 kod oluşturulmuştur (Tablo 11).

Oluşturulan kodlar incelendiğinde 18 öğretmen uzaktan eğitim sürecinde öğrencilerin psikolojik açıdan olumuz yönde etkilendiğini, 1 öğretmen sürecin teknolojik bağımlılığa yol açtı̆̆ını, 1 öğretmen uzaktan eğitim sürecinin derse ilgi ve motivasyon düzeyini düşürdüğünü, 1 öğretmen öğrencilerde temizlik ve hijyen takıntısı oluştuğunu belirtmiştir. Sosyal yönlerden bakıldığında 12 öğretmen sosyal iletişim, etkileşim becerilerini geliştirme firsatlarının kısıtlı olduğunu, 8 öğretmen öğrencilerin aileleri ile daha çok vakit geçirme şansının olduğunu, 1 öğretmen kişisel gelişim için yeterince zamanlarının olduğunu görüşündedir. Fiziksel yönler bakımından 4 öğretmen öğrencilerde sağlık açısından olumsuz etkilerinin olduğunu, 10 öğretmen öğrencilerde hareketsiz yaşam ve kilo problemlerine yol açtığını, 1 öğretmen temizlik ve hijyen takıntısı sebebi ile ellerde alerji oluşmasına sebep olduğunu belirtmiştir (Tablo 11). 
Tablo 11: Uzaktan Eğitim Sürecinde Evde Kalmak Zorunda Olan Öğrencilerin Sosyal, Fiziksel ve Psikolojik Durumlarına İlişkin Veriler

\begin{tabular}{|c|c|c|c|c|c|c|c|}
\hline & Temalar & Kodlar & $\begin{array}{l}\text { Anasınıfi } \\
\text { Öğrt. (f) }\end{array}$ & $\begin{array}{l}\text { İlkokul } \\
\text { Öğrt. (f) }\end{array}$ & $\begin{array}{l}\text { Ortaokul } \\
\text { Öğrt. (f) }\end{array}$ & $\begin{array}{l}\text { Özel } \\
\text { Eğitim } \\
\text { Öğrt. (f) }\end{array}$ & $\begin{array}{l}\text { Toplam } \\
\text { (f) }\end{array}$ \\
\hline \multirow{4}{*}{1.} & \multirow{4}{*}{$\begin{array}{l}\text { Psikolojik } \\
\text { etkiler }\end{array}$} & $\begin{array}{l}\text { 1-Öğrencilerin } \\
\text { olumsuz yönde } \\
\text { etkilenmesi }\end{array}$ & $\begin{array}{l}\mathrm{A} 1, \mathrm{~A} 2, \mathrm{~A} 5, \\
\mathrm{~A} 7, \mathrm{~A} 8 /(5)\end{array}$ & $\begin{array}{l}\dot{\mathrm{I} 2} 2, \dot{\mathrm{I}} 6, \dot{\mathrm{I}} 7, \\
\text { İ10, İ18, } \\
\dot{\mathrm{I}} 19 /(6)\end{array}$ & $\begin{array}{l}\text { O5, O6, } \\
\text { O10/ (3) }\end{array}$ & $\begin{array}{l}\text { Ö2, Ö3, } \\
\text { Ö4, Ö5/ (4) }\end{array}$ & 18 \\
\hline & & $\begin{array}{l}\text { 2-Teknolojik } \\
\text { bağımlılığa yol } \\
\text { açması }\end{array}$ & & İ14/ (1) & & & 1 \\
\hline & & $\begin{array}{l}\text { 3-Derse ilişkin } \\
\text { ilginin ve } \\
\text { motivasyonun } \\
\text { düşmesi }\end{array}$ & & İ15/ (1) & & & 1 \\
\hline & & $\begin{array}{l}\text { 4-Temizlik ve } \\
\text { hijyen takıntısı } \\
\text { oluşması }\end{array}$ & A7/ (1) & & & & 1 \\
\hline \multirow{3}{*}{2.} & \multirow{3}{*}{$\begin{array}{l}\text { Sosyal } \\
\text { etkiler }\end{array}$} & $\begin{array}{l}\text { 1-Sosyal iletişim, } \\
\text { etkileşim } \\
\text { becerilerini } \\
\text { geliştirme } \\
\text { firsatlarının kısıtlı } \\
\text { olması }\end{array}$ & A5/ (1) & 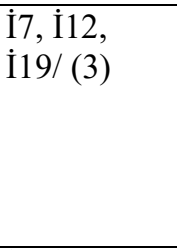 & $\begin{array}{l}\mathrm{O} 1, \mathrm{O} 2, \\
\mathrm{O} 5, \mathrm{O} 6 /(4)\end{array}$ & $\begin{array}{l}\text { Ö1, Ö3, } \\
\text { Ö4, Ö5/ (4) }\end{array}$ & 12 \\
\hline & & $\begin{array}{l}\text { 2-Aileleri ile daha } \\
\text { çok vakit geçirme } \\
\text { imkânının olması }\end{array}$ & $\begin{array}{l}\text { A2, A6, } \\
\text { A8, A9/ (4) }\end{array}$ & $\dot{\mathrm{I}} 5, \mathrm{I} 18 /(2)$ & $\mathrm{O} 2, \mathrm{O} 5 /(2)$ & & 8 \\
\hline & & $\begin{array}{l}\text { 3-Kişisel gelişim } \\
\text { için yeterince } \\
\text { zaman olmas1 }\end{array}$ & & & O3/ (1) & & 1 \\
\hline \multirow{3}{*}{3.} & \multirow{3}{*}{$\begin{array}{l}\text { Fiziksel } \\
\text { etkiler }\end{array}$} & $\begin{array}{l}\text { 1-Sağlık açısından } \\
\text { olumsuz etkilerinin } \\
\text { olmas1 }\end{array}$ & A4/ (1) & $\begin{array}{l}\mathrm{İ} 19 /(1) \\
\end{array}$ & & Ö3, Ö5/ (2) & 4 \\
\hline & & $\begin{array}{l}\text { 2-Hareketsiz } \\
\text { yaşamları ve kilo } \\
\text { problemlerinin } \\
\text { olması }\end{array}$ & $\begin{array}{l}\text { A5, A6, } \\
\text { A7, A8, } \\
\text { A9/ (5) }\end{array}$ & İ́, İ12/ (2) & $\mathrm{O} 1, \mathrm{O} 6 /(2)$ & Ö4/ (1) & 10 \\
\hline & & $\begin{array}{l}\text { 3-Temizlik ve } \\
\text { hijyen takıntıs1 } \\
\text { sebebi ile ellerde } \\
\text { alerji oluşması }\end{array}$ & A7/ (1) & & & & 1 \\
\hline
\end{tabular}

Öğretmenlerin uzaktan eğitim sürecinde evde kalmak zorunda olan öğrencilerin (sosyal, fiziksel ve psikolojik) durumlarının olumlu/olumsuz yönlerine ilişkin yazdıkları incelendiğinde "Genellikle çocuklarımla konuştuğumda onlardan çok sıkıldıklarını, artık okula gelmek istediklerini duyuyorum. Bu süreç onlart psikolojik olarak olumsuz etkiledi (A1)”, "Öğrencilerimiz uzaktan eğitim surecinde sosyal ve fiziksel etkinliklere katılamadıklart için psikolojik olarak olumsuz yönde etkilenmişlerdir. Sosyal hayatin gerekliliği olan sosyal yasam kuralların ögrenememektedirler. Yeterli fiziksel aktivite yapamamakta bu nedenle kaslarda zayıflama ve fazla kilo alma durumlar gözlemlenmektir (A5)”, "Aileleriyle daha fazla zaman geçirmeleri olumlu olsa da arkadaşlarından uzak kalmak ve fiziksel aktivitelerden yeterince faydalanamamaları ciddi problemlere sebebiyet verebilir (I5)", "3 alanda da çocuklarımız dezavantajlı durumda, uzaktan eğitim bunu bi nebze olumlu etkiledi fakat yine de teneffüs eksikliği, fiziksel aktivite yoksunluğu ve sosyal fakirligin telafisi uzaktan eğitim ile yapılamaz (O6)" ve "Özel öğrencilerimiz en çok yaşam becerilerinin gelişstirilmesine ihtiyaç duymaktadırlar. Uzaktan eğitim çalışmalarında; Öğrencilerin 
sosyal ve psikolojik ihtiyaçları karşılanamamaktadır. Fiziksel ihtiyaçları ise çok sınırlı karşılanmaktadır (Ö4)" şeklinde görüş belirttikleri görülmektedir.

$\mathrm{Bu}$ bulgulardan anlaşılacağı üzere, öğretmenlerin çoğunun görüşüne göre, uzaktan eğitim sürecinde öğrencilerin psikolojik, sosyal ve fiziksel açıdan olumsuz yönde etkilendiği, bununla birlikte bazı öğretmenler, bu süreçte öğrencilerin aileleriyle daha fazla vakit geçirme şansı bulduğu görüşlerini ortaya koymuştur.

\section{Yüz Yüze Eğitim ile Uzaktan Eğitimi Karşılaştıracak Olursanız Neler Söylersiniz? Sorusuna İlişkin Bulgular.}

Öğretmenlerin yüz yüze eğitim ile uzaktan eğitimin karşılaştırılmasına ilişkin görüşlerine Tablo 12'de yer verilmiştir.

Bu soruya ilişkin 4 tema oluşturulmuştur. "Eğitim tercihi" temasında yüz yüze eğitimi tercih ederim (f:36), uzaktan eğitimi tercih ederim (2) olmak üzere 2 kod belirlenmiştir. "Uzaktan eğitimin olumlu yanları" temasında zamandan ve mekândan tasarruf sağlaması (f:1), aile katılımını ve desteğini artırması (f:1), yüz yüze eğitimin tamamlayıcısı olması (f:6), olağanüstü durumlarda alternatif olması (f:4) olmak üzere 4 kod belirlenmiştir. "Uzaktan eğitimin olumsuz yanları" temasında küçük yaş grupları için uygun olmaması (f:3), sosyalleşme, duygu aktarımı ve geri dönüt sağlama konusunda yetersiz olması (f:10), eğitimin tüm alanlarında kullanılamaması (f:1), zaman ve planlamanın kısıtlı olması (f:1) olmak üzere 4 kod belirlenmiştir. Yine "Yüz yüze eğitimin olumlu yanları" temasında yaparak yaşayarak ve uygulamalı öğrenme firsatı sunması (f:5), özel gereksinimli öğrenciler için en uygun yöntem olması (f:3), sosyal etkileşim, somut yaşantı ve yüksek motivasyon sağlaması (f:8) olmak üzere 3 kod oluşturulmuştur (Tablo 12).

Oluşturulan kodlar incelendiğinde 36 öğretmen yüz yüze eğitime tercih ettiğini, 2 öğretmen uzaktan eğitimi tercih ettiği görülmektedir. Uzaktan eğitimin olumlu yönleri açısından, 1 öğretmen zamandan ve mekândan tasarruf sağladığını, 1 öğretmen aile katılımını ve desteğini artırdığını, 6 öğretmen yüz yüze eğitimin tamamlayıcısı olduğunu, 4 öğretmen olağanüstü durumlarda alternatif olduğunu belirtmiştir (Tablo 12).

Uzaktan eğitimin olumsuz yanları açısından 3 öğretmen küçük yaş grupları için uygun olmadığını, 10 öğretmen sosyalleşme, duygu aktarımı ve geri dönüt sağlama konusunda yetersiz olduğunu, 1 öğretmen eğitimin tüm alanlarında kullanılamadığını, 1 öğretmen zaman ve planlamanın kısıtlı olduğunu görüşündedir. Yüz yüze eğitimin olumlu yanları açısından 5 öğretmen yaparak yaşayarak ve uygulamalı öğrenme firsatı sunduğunu, 3 öğretmen özel gereksinimli öğrenciler için en uygun yöntem olduğunu, 8 öğretmen sosyal etkileşim, somut yaşantı ve yüksek motivasyon sağladı ğını belirtmiş̧tir (Tablo 12).

Öğretmenlerin yüz yüze eğitim ile uzaktan eğitimin karşılaştırılmasına ilişkin yazdıkları incelendiğinde; "Kesinlikle yakından eğitim yakından ilgi. Uzaktan eğitimde her ne kadar arasan, görüntülü konuşsan çocuğun yanında onunla oyun oynamanın yerini tutmuyor. Sabah onları günaydın diye karşılamanın, öğretmenim sen hep burada mı yaşıyorsun sorusu ile karşılaşmanın, kışın beraber dışarı çıkarken aaa seninde mi montun var şaşkınlığını görmenin, gözlerine bakarak kitap okumanın, beslenme saatinde boğazlarından bensiz gecmeyen lokmalalarının avucumun içine doluşturulmasının, öğretmenim senin bir sürü çocuğun var demi sözlerinin yerini hiç şey tutmuyor (A2)", "Etkileşim ve geri dönüt kesinlikle yüz yüze eğitimin en değerli unsurlarldır. Maalesef uzaktan eğitimle bu durum yeterli düzeyde mümkün olamamaktadır (I5)", "Yüz yüze eğitim temel eğitim yaklaşımıdır. Uzaktan eğitim ancak ona destek olarak yer alabilir (O9)" ve "Yüz yüze eğitim en başarıl eğitim ve gerekli olan eğitimdir (Ö5)" ş̧eklinde görüşlerini dile getirdikleri görülmektedir. $\mathrm{Bu}$ bulgular 1şı̆̆ında öğretmenlerin büyük çoğunluğu yüz yüze eğitimi tercih ettiğini, bazı öğretmenler uzaktan eğitimin sosyalleşme, duygu aktarımı ve geri dönüt sağlama konusunda yetersiz kaldığını, bazı öğretmenlerse uzaktan eğitimin ancak yüz yüze eğitimi 
desteklemek amacıyla kullanılabileceği göürüşünü ortaya koymakta ve yüz yüze eğitimin öğretmenlerce tercih edilen yaklaşım olduğu anlaşılmaktadır.

Tablo 12: Yüz Yüze Eğitim ile Uzaktan Eğitimin Karşılaştırılmasına İlişkin Veriler

\begin{tabular}{|c|c|c|c|c|c|c|c|}
\hline & Temalar & Kodlar & $\begin{array}{l}\text { Anasınıfi } \\
\text { Öğrt. (f) }\end{array}$ & $\begin{array}{l}\text { İlkokul } \\
\text { Öğrt. (f) }\end{array}$ & $\begin{array}{l}\text { Ortaokul } \\
\text { Öğrt. (f) }\end{array}$ & $\begin{array}{l}\text { Özel } \\
\text { Eğitim } \\
\text { Öğrt. (f) }\end{array}$ & Toplam (f) \\
\hline \multirow[t]{2}{*}{1.} & \multirow[t]{2}{*}{$\begin{array}{l}\text { Eğitim } \\
\text { tercihi }\end{array}$} & $\begin{array}{l}\text { 1-Yüz yüze } \\
\text { eğitimi tercih } \\
\text { ederim }\end{array}$ & $\begin{array}{l}\text { A1, A4, A6, } \\
\text { A7, A9/ (5) }\end{array}$ & $\begin{array}{l}\dot{\mathrm{I}} 1, \mathrm{I} 2, \dot{\mathrm{I}} 3, \\
\text { İ4, İ5, İ6, } \\
\text { İ7, İ8, İ9, } \\
\text { İ10, İ11, } \\
\text { İ12, İ13, } \\
\text { İ14, İ15, } \\
\text { İ16, İ18, } \\
\text { İ20/ (18) }\end{array}$ & $\begin{array}{l}\text { O2, O4, } \\
\text { O5, O6, } \\
\text { O7, O8, } \\
\text { O9, O10/ } \\
(8)\end{array}$ & $\begin{array}{l}\text { Ö1, Ö2, } \\
\text { Ö3, Ö4, } \\
\text { Ö5/ (5) }\end{array}$ & 36 \\
\hline & & $\begin{array}{l}\text { 2-Uzaktan eğitimi } \\
\text { tercih ederim }\end{array}$ & A8/ (1) & & O1/ (1) & & 2 \\
\hline \multirow{4}{*}{2.} & \multirow{4}{*}{$\begin{array}{l}\text { Uzaktan } \\
\text { eğitimin } \\
\text { olumlu } \\
\text { yanları }\end{array}$} & $\begin{array}{l}\text { 1-Zamandan ve } \\
\text { mekândan tasarruf } \\
\text { sağlamas1 }\end{array}$ & $\mathrm{A} 3 /(1)$ & & & & 1 \\
\hline & & $\begin{array}{l}\text { 2-Aile katılımını } \\
\text { ve desteğini } \\
\text { artırması }\end{array}$ & A8/ (1) & & & & 1 \\
\hline & & $\begin{array}{l}\text { 3-Yüz yüze } \\
\text { eğitimin } \\
\text { tamamlayıcıs1 } \\
\text { olmas1 }\end{array}$ & & $\begin{array}{l}\dot{\mathrm{I}} 6, \dot{\mathrm{I}} 12, \\
\mathrm{I} 13, \dot{\mathrm{I}} 16 / \\
(4)\end{array}$ & $\begin{array}{l}\text { O8, O9/ } \\
(2)\end{array}$ & & 6 \\
\hline & & $\begin{array}{l}\text { 4-Olağanüstü } \\
\text { durumlarda } \\
\text { alternatif olmas1 }\end{array}$ & & İं20/ (1) & $\begin{array}{l}\text { O1, O6/ } \\
(2)\end{array}$ & Ö3/ (1) & 4 \\
\hline \multirow{4}{*}{3.} & \multirow{4}{*}{$\begin{array}{l}\text { Uzaktan } \\
\text { eğitimin } \\
\text { olumsuz } \\
\text { yanları }\end{array}$} & $\begin{array}{l}\text { 1-Küçük yaş } \\
\text { grupları için } \\
\text { uygun olmamas1 }\end{array}$ & A6/ (1) & İं20/ (1) & O4/ (1) & & 3 \\
\hline & & $\begin{array}{l}\text { 2-Sosyalleşme, } \\
\text { duygu aktarımı ve } \\
\text { geri dönüt } \\
\text { sağlama } \\
\text { konusunda } \\
\text { yetersiz olması }\end{array}$ & $\begin{array}{l}\text { A2, A3, A5, } \\
\text { A7/ (4) }\end{array}$ & $\begin{array}{l}\text { İ5, İ10, } \\
\text { İ12, İ13, } \\
\text { İ14, İ18/ } \\
\text { (6) }\end{array}$ & & & 10 \\
\hline & & $\begin{array}{l}\text { 3-Eğitimin tüm } \\
\text { alanlarında } \\
\text { kullanılamaması }\end{array}$ & $\mathrm{A} 5 /(1)$ & & & & 1 \\
\hline & & $\begin{array}{l}\text { 4-Zaman ve } \\
\text { planlamanın } \\
\text { k1sitlı olmas1 }\end{array}$ & & İं17/ (1) & & & 1 \\
\hline \multirow{2}{*}{4.} & \multirow{2}{*}{$\begin{array}{l}\text { Yüz yüze } \\
\text { eğitimin } \\
\text { olumlu } \\
\text { yanları }\end{array}$} & $\begin{array}{l}\text { 1-Yaparak } \\
\text { yaşayarak ve } \\
\text { uygulamalı } \\
\text { öğrenme firsat1 } \\
\text { sunması }\end{array}$ & $\mathrm{A} 6 /(1)$ & $\begin{array}{l}\mathrm{İ} 14, \mathrm{I} 18, \\
\text { İ19/ (3) }\end{array}$ & O3/ (1) & & 5 \\
\hline & & $\begin{array}{l}\text { 2-Özel } \\
\text { gereksinimli } \\
\text { öğrenciler için en } \\
\text { uygun yöntem } \\
\text { olması }\end{array}$ & & & & $\begin{array}{l}\text { Ö1, Ö3, } \\
\text { Ö4/ (3) }\end{array}$ & 3 \\
\hline
\end{tabular}




\begin{tabular}{|c|c|c|c|c|}
\hline $\begin{array}{l}\text { 3-Sosyal etkileşim, } \\
\text { somut yaşantı ve } \\
\text { yüksek motivasyon } \\
\text { sağlaması }\end{array}$ & $\begin{array}{l}\text { A2, A3,A5, } \\
\text { A7/ (4) }\end{array}$ & $\begin{array}{l}\mathrm{İ} 10, \dot{\mathrm{I}} 12, \\
\mathrm{I} 13 /(3)\end{array}$ & Ö3/ (1) & 8 \\
\hline
\end{tabular}

\section{Tartışma ve Sonuç}

Araştırma kapsamında Covid-19 küresel salgını döneminde gerçekleştirilen uzaktan eğitim sürecinin değerlendirilmesine ilişkin okulöncesi, ilkokul, ortaokul ve özel eğitim öğretmenlerinin görüşleri incelenmiştir. Milli Eğitim Bakanlığg uzaktan eğitim süresince, Eğitim Bilişim Ağı, TRT, sosyal medya ve çevrimiçi programlar aracılığıyla öğrencilerin kişisel gelişim ve psikolojik ihtiyaçlarının karşılanmasına yönelik çalışmalar gerçekleştirmektedir. Öğretmenlerin Eğitim Bilişim Ağı üzerinden canlı ders anlatabilmesi, öğrencilerin kendileri için planlanan saatlerde derslerini takip edebilmeleri uzaktan eğitim sürecine katkı sağlamıştır. Bununla birlikte tüm öğrenciler için yeterli ders saati planlaması konusunda problemler olduğu, özellikle ilk zamanlarda alt yapı yetersizliğine bağlı bağlantı sorunları yaşandığı, bazı öğrencilerin internet ve donanımsal araçlar yetersizliği sebebi ile eğitim içeriklerine dâhil olamadıkları öğretmenlerce ifade edilmiştir. Bu süreci daha etkin kılmak öğrencilerle iletişimi artırmak adına Milli Eğitim Bakanlığı tarafından bazı web araçlarının kullanımına izin verilmiştir. Öğretmenlerin, uzaktan eğitim sürecinde daha çok "Telefonla arama yaparak, Whatsapp, Telegram vb., Zoom, Skype, Adobe Connect vb." yollarla öğrencilerle iletişim kurdukları ve çoğu öğretmenin birden fazla iletişim aracını kullandığı, az sayıda öğretmenin yalnızca telefonla arayarak öğrencisi ile iletişim kurduğu belirlenmişsir.

Araştırma sonucunda öğretmenlerin büyük çoğunluğunun uzaktan eğitim konusunda kendini yeterli ve orta düzeyde yeterli gördüğü, deneyimi ve yeterliği olmayanların birçoğunun ise uzaktan eğitim süreci içerisinde kendilerini geliştirdikleri ve yeterliklerini artırdıkları, bazılarının ise kendisini yetersiz gördüğü belirlenmiştir. Öğretmenlerin çoğunluğunun uzaktan eğitime hızlı bir şekilde uyum sağladığı ve yeterliklerini artırdığı görülmektedir. Yapılan araştırmada, öğretmenlerin çoğu uzaktan eğitime uyum sağlama konusunda başarı gösterirken; Gürer, Tekinarslan ve Yavuzalp (2016) tarafından yapılan araştırmada öğretim elemanlarının derslerini tamamen çevrimiçi olarak sunmaya yönelik dirençlerinin olduğu ve öğretim elemanlarının daha önce çevrimiçi olarak ders verme tecrübelerinin olmaması sebebiyle ortaya çıkmış olabileceği ortaya konulmuştur. Yapılan araştırmada bazı öğretmenler ise uzaktan eğitim konusunda kendilerini yetersiz gördüklerini belirtmişlerdir. Külekçi Akyavuz ve Çakın (2020) tarafından yapılan araştırmada; öğretmenlerin bilgi eksikliğinin olması ve yeterince uzaktan eğitime ilgi göstermemeleri bulguları ile yapılan araştırmanın bulguları örtüşmektedir. $\mathrm{Bu}$ anlamda öğretmenlerin yeterliklerini artırmak adına zenginleştirilmiş ve çeşitli içeriklerin geliştirilebilmesi amacıyla eğitimcilere e-içerik geliştirme eğitimleri verilmesi geliştirilen içeriklerin mobil uyumlu olması önerilmektedir (Özbay, 2015).

Uzaktan eğitim sürecinde, öğretmenlerin yarısından fazlası alt yapının yeterli olduğu, bazı öğretmenler ise özellikle öğrencilerin mevcut imkânlarından kaynaklanan eksiklikler sebebiyle uzaktan eğitime erişim konusunda sıkıntı yaşandığı görüşlerini ortaya koymuştur. Bakioğlu ve Çevik (2020) tarafından yapılan araştımada da benzer şekilde öğrencilerin; internet bağlantısı, iletişim ve derse erişim konularında sorunlar yaşandığı belirlenmiştir. Uzaktan eğitim sürecinde alt yapının yeterli düzeyde olması ve öğrenci ve öğretmenlerin erişim sağlamada karşılaşabilecekleri sorunlara anında çözüm üretilmesinin önemli olduğu görülmüştür. Yapılan araştırmanın bulgusunu destekler şekilde, Bilgiç ve Tüzün (2015) tarafından yapılan araştırmada uzaktan eğitim sürecinde, doğru teknolojilerin seçimi, kullanılan yazılım ve sistemlerin birbiri ile entegrasyonunun yapılması, sistemler için ön gereksinimlerin doğru tanımlanması ve ortaya çıkabilecek teknik sorunlara anlık çözümler üretebilecek alt yapının oluşturulmasının önemli olduğu ortaya konulmuştur. 
Uzaktan eğitime erişim konusunda en fazla problemin; öğrencilerin internetlerinin olmaması, öğrencilerin donanımsal araçlarının yetersizliği, velilerin teknolojik bilgi eksikliği, öğrencilerinin bireysel özellikleri sebebiyle uzaktan eğitime erişim konusunda sıkıntı yaşandığı; özellikle küçük yaş gruplarındaki öğrenciler ile özel gereksinimli öğrencilerin çeşitli zorluklarla ve kısıtlılıklarla karşılaştı̆̆ı, öğrencilerin motivasyonlarının ve derse olan dikkatlerinin daha düşük olduğu, alt yapıdan kaynaklanan sorunlar sebebiyle uzaktan eğitim sürecinin olumsuz yönde etkilendiği belirlenmiştir. Bu sonuç, Kuru, Kaşkaya ve Calp (2017) tarafından yapılan "İlkokul 4. Sınıf Öğrencilerinin Kâğıttan ve Ekrandan Okuduğunu Anlama Becerilerinin Sınanması; Öğretmen ve Öğrenci Görüşleri” konulu araştırmanın, ilkokul öğrencilerinin eğitiminde bilgisayar ve teknolojinin, kitabın ve öğretmenin destekleyicisi olması, ancak önüne geçmemesi gerektiği bulgusu ile benzerlik göstermektedir.

Yüz yüze yapılan eğitim ortamlarında öğrencilerle bire bir iletişim ve öğrencilerle göz temasının olması, öğrencilerin sınıf içindeki bireysel durumlarının rahatça gözlemlenebilmesi mümkünken çevrimiçi olarak yapılan eğitimlerde öğrenci ile göz teması kurulamadığı için, öğrenci pasif kalabilmektedir (Gürer, Tekinarslan ve Yavuzalp, 2016). Benzer şekilde Kaleli Y1lmaz ve Güven (2015) tarafından yapılan araştırmada öğretmen adaylarının uzaktan eğitimi sıkıcı, verimsiz, etkileşimsiz, duygusuz ve geri dönüt sağlanamayan bir iletişim olarak gördükleri belirlenmiştir. Bu durum sebebiyle yapılan araştırmada da uzaktan eğitim sürecinde, öğrencilerin motivasyonlarının düşük olduğu, bununla birlikte öğrencilerin derse katılım gösterdiği, öğrencilerin bireysel özellikleri sebebiyle derse katılım ve motivasyon durumlarının farklılık gösterebildiği ortaya çıkarılmıştır. Yapılan araştırmada uzaktan eğitim sürecinde öğrencilerin motivasyonlarının düşük olduğu belirlenmiştir. Uzaktan eğitim derslerinde animasyon, video ve simülasyon gibi etkileşime dayalı materyallerin kullanılması ile öğrencilere verilen eğitimin daha verimli hale geldiği (Kör, Çataloğlu ve Erbay, 2013), bu nedenle öğrencilerin motivasyonlarını ve derse katılımlarını artırmak için benzer içeriklerin kullanılmasının faydalı olacağı düşünülmektedir.

Velilerin büyük ölçüde uzaktan eğitim sürecine destek olduğu, uzaktan eğitime ilişkin farkındalık, velilerin iş yoğunluğu gibi durumlara bağlı olarak uzaktan eğitim sürecini destekleme durumlarının değişkenlik gösterdiği belirlenmiştir. Uzaktan eğitim sürecinde dezavantajlı durumda olan öğrencilerin yeterince eğitimden yararlanamadığı, uzaktan eğitimin bu grupta yer alan öğrencilere çok uygun olmadığı, öğrencilerin bireysel özellikleri nedeniyle kısıtll bir ölçüde uzaktan eğitim imkânlarından yararlanabildikleri anlaşılmaktadır.

Uzaktan eğitimle müfredatın tam anlamıyla uygulanamadığı, bazı derslerin ve kazanımların uzaktan eğitimle uygulama yapmaya imkân vermediği belirlenmiştir. Tüm öğretim kademelerinde açık ve uzaktan eğitim kapsamında öğrencilerin ulaşabileceği nitelikli müfredat içeriklerinin sağlanmas1 gerekmektedir (Can, 2020).

Uzaktan eğitimle yeterli iletişim, etkileşim ve geri dönüt sağlanamaması, öğrencilerin tümüne erişim sağlanamaması, teknoloji bağımlılığı, hareketsiz yaşam ve sağlık sorunlarına sebep olması, öğrencilerin motivasyonlarının düşük olması gibi olumsuz yanlarının yanı sıra; uzaktan eğitimin yaygın hastalık döneminde eğitim firsatları ve imkânları sunması, yüz yüze eğitimi desteklemesi, zamandan ve mekândan tasarruf sağlaması gibi olumlu yanlarının da olduğu ortaya konulmuştur. Uzaktan eğitimin, eğitime katılacak öğrenci kapasitesini sınırlayan bina, derslik, öğretmen, eğitim materyali gibi birçok konuda yüzü yüze eğitimde gerekli unsurlardan farklılaştığı ve eğitim maliyetinin düşmesinde de önemli bir katkısının olduğu görülmektedir (Kırık, 2014; Özbay, 2015).

Covid-19 küresel salgını sebebiyle hızlı bir şekilde hayatımıza giren uzaktan eğitim sürecinin, tüm dünyada insanların kullanmak durumunda kalacağı ana öğrenme yapısı haline gelebileceği (Telli Yamamoto ve Altun, 2020), bu anlamda Milli Eğitim Bakanlığı yetkililerince Türkiye'de uzaktan eğitim sisteminin altyapı, erişim, içerik, tasarım, uygulama, kalite, güvenlik, mevzuat ve pedagojik açıdan güçlendirilmesi gerektiği (Can, 2020) anlaşılmaktadır. 
Yapılan araştırmada, uzaktan eğitim sürecinde öğrencilerin psikolojik, sosyal ve fiziksel açıdan olumsuz yönde etkilendiği belirlenmiştir. Bununla birlikte bu süreçte öğrencilerin aileleriyle daha fazla vakit geçirme şansı bulduğu, süreci iyi değerlendirebilen öğrencilerin kişisel gelişim fırsatlarını yakaladıkları belirlenmiştir. Uzaktan eğitimin sosyalleşme, duygu aktarımı ve geri dönüt sağlama konusunda yetersiz kalması sebebiyle öğretmenlerin büyük çoğunluğunun yüz yüze eğitimi tercih ettiği, uzaktan eğitimin ancak yüz yüze eğitimi desteklemek amaciyla kullanılabileceği ve yüz yüze eğitimin öğretmenlerce öncelikle tercih edilen bir yaklaşım olduğu anlaşılmaktadır.

\section{Öneriler}

Öğrencilerin yaş gruplarına göre uzaktan eğitim öncesi öz yeterlik algılarının ölçülmesi, öğrencilerin pedagojik özellikleri dikkate alınarak, dikkat süresi ve motivasyonlarını artıracak içeriklerin geliştirilmesi önemlidir.

Öğretmenlerin uzaktan eğitim ile ders işleme yaklaşımları ve teknolojik yeterliklerinin artırılmasına yönelik hizmet içi eğitimlere katılması, okul öncesi, ilkokul ve özel eğitim öğrencilerinin uzaktan eğitim sürecinde yararlanabilecekleri içeriklerin artırılması faydalı olacaktır.

Uzaktan eğitimin tek başına uygulanmasının gerektiği durumlarda sınırsız internet ve gerekli alt yapı hizmetlerinin sağlanması için Milli Eğitim Bakanlığınca gerekli önlemlerin alınması, olağanüstü durumlarda devreye sokulabilecek uzaktan eğitim yaklaşımlarının geliştirilmesi önerilmektedir.

Velilerin uzaktan eğitim hakkında bilgilendirilmesi, teknolojik farkındalıklarını artıracak çalışmaların yapılması, ögrencilerin evde kalmasını gerektirecek olağanüstü durumlarda uzaktan eğitim sürecinde psikolojik, sosyal ve fiziksel anlamda sağlığını koruyabileceği etkinlik programlarının geliştirilmesi ve öncesinde öğrencilere gereken yeterliklerin kazandırılması, öğrencilerin bireysel gelişimlerine uygun, ölçme ve değerlendirme açısından kendi hızında ilerleyebileceği ve geri dönüt sağlayabilen içeriklerin geliştirilmesi ve planlanması süreçlerin başarısı açısından önemlidir.

Uzaktan eğitim sürecinde öğrencilerin ve velilerin karşılaştıkları problemleri ele alan ve farklı kademelerde ve branşlarda görev yapan öğretmenlere yönelik araştırmaların yapılması alana katkı sağlayacaktır.

\section{Kaynakça}

Altıparmak, M., Kurt, İ. D. \& Kapıdere, M. (2011). E-öğrenme ve uzaktan eğitimde açık kaynak kodlu öğrenme yönetim sistemleri. XI. Akademik Bilişim Kongresi. Erişim adresi: https://ab.org.tr/ab11/kitap/altiparmak_kurt_AB11.pdf

Bakioğlu, B., Çevik, M. (2020). COVID-19 pandemisi sürecinde fen bilimleri öğretmenlerinin uzaktan eğitime ilişkin görüşleri. Turkish Studies, 15(4), 109-129. https://dx.doi.org/10.7827/TurkishStudies.43502

Bilgiç, H. G. \& Tüzün, H. (2015). Yükseköğretim kurumları web tabanlı uzaktan eğitim programlarında yaşanan sorunlar. AUAd, 1(3), 26-50. Erişim adresi: http://yunus.hacettepe.edu.tr/ htuzun/html/academic/Bilgic_Tuzun_2015_AUAD.pdf

Bolliger, D. U. \& Wasilik, O. (2009). Factors influencing faculty satisfaction with online teaching and learning in higher education. Distance Education, 30(1), 103-116. https://doi.org/10.1080/01587910902845949

Bozkurt, A. (2017). Türkiye'de uzaktan eğitimin dünü, bugünü ve yarını. AUAd, 3(2), 85-124. Erişim adresi: https://dergipark.org.tr/en/download/article-file/403827 
Büyüköztürk, Ş., Kılıç Çakmak, E., Akgün, Ö., E., Karadeniz, Ş. \& Demirel, F. (2018). Eğitimde bilimsel araştırma yöntemleri. Pegem Akademi Yayıncılık.

Can, E. (2020). Coronavirüs (Covid-19) pandemisi ve pedagojik yansımaları: Türkiye'de açık ve uzaktan eğitim uygulamaları. $A U A d, \quad 6(2)$, 11-53. Erişim adresi: http://auad.anadolu.edu.tr/yonetim/icerik/makaleler/515-published.pdf

Gürer, M., D., Tekinarsan, E. \& Yavuzalp, N. (2016). Çevrimiçi ders veren öğretim elemanlarının uzaktan eğitim hakkındaki görüşleri. Turkish Online Journal of Qualitative Inquiry (TOJQI),7(1), 47-78. DOI: 10.17569/tojqi.74876

Kaleli Yılmaz, G. \& Güven, B. (2015).Öğretmen adaylarının uzaktan eğitime yönelik algılarının metaforlar yoluyla belirlenmesi. Turkish Journal of Computer and Mathematics Education, 6 (2), 299-322. https://doi.org/10.16949/turcomat.75936

Kırık, A., M. (2014). Uzaktan eğitimin tarihsel gelişimi ve Türkiye'deki durumu. Marmara İletişim Dergisi, (21), 73-94. DOI: 10.17569/tojqi.74876

Kör, H., Çataloğlu, E. \& Erbay, H. (2013).Uzaktan ve örgün eğitimin öğrenci başarıs1 üzerine etkisinin araştırılması. Gaziantep University Journal of Social Sciences, 12(2), 267-279. Erişim adresi: https://dergipark.org.tr/tr/download/article-file/223274

Kuru, O., Kaşkaya, A. \& Calp Ş. (2017). İlkokul 4. sınıf öğrencilerinin kâğıttan ve ekrandan okuduğunu anlama becerilerinin sınanması; öğretmen ve öğrenci görüssleri. Sosyal Bilimler Dergis,7(13), 70-84. Erişim adresi: http://web.a.ebscohost.com/ehost/pdfviewer/pdfviewer?vid=2\&sid=ed53c328-edfb-4771ac69-867bbf02ac2a\%40sessionmgr4008

Külekçi Akyavuz, E., Çakın, M. (2020). Covid-19 salgınının eğitime etkisi konusunda okul yöneticilerinin görüşleri. Turkish $\quad$ Studies, 15(4), 723-737. https://dx.doi.org/10.7827/TurkishStudies.44140

Miles, M. B. \& Huberman, A. M. (1994). Qualitative Data Analysis. London: Sage Publication.

Milli Eğitim Bakanlığ1, (2019). Millî Eğitim İstatistikleri Örgün Eğitim 2018-2019 (http://sgb.meb.gov.tr/www/icerik_goruntule.php?KNO=361). $31.05 .2020 \quad$ tarihinde erişilmiştir.

Milli Eğitim Bakanlığı, (2020a), sayı:5497866.

Milli Eğitim Bakanlığı, (2020b), sayı:5926009.

Milli Eğitim Bakanlığı, (2020c). Yenilik ve Eğitim Teknolojileri Genel Müdürlüğü, Sanal sınıf uygulamaları. (https://www.memurlar.net/haber/899781/meb-den-zoom-skypeteamsaciklamasi.html. 31.05.2020) tarihinde erişilmiştir.

Miltiadou, M. \& Yu, C. H. (2000). Validation of the Online Technologies Self-Efficacy Scale (OTSES). ERIC. Erişim adresi: https://files.eric.ed.gov/fulltext/ED445672.pdf

Özbay, Ö. (2015). Dünyada ve Türkiye'de uzaktan eğitimin güncel durumu. Uluslararası Eğitim Bilimleri Dergisi, 2(5), 376-394. DOI: 10.16991/INESJOURNAL.174

Özer, M. (2020). Educational policy actions by the ministry of national education in the times of COVID-19. Kastamonu Education Journal, 28(3), 1124-1129. doi: 10.24106/kefdergi.722280

Saban, A. ve Ersoy, A. (2016). Eğitimde Nitel Araştırma Desenleri. Anı yayıncılık. 
Sari Yanartas, M. \& Hancerli Torun, S. (2020). COVID-19 and Child. Sağllk Bilimlerinde İleri Araştırmalar Dergisi 2020; 3(Suppl.1), S40-S48. https://doi.org/10.26650/JARHS2020S1-0005

T.C. Resmi Gazete, 22 Mart 2020a, say1:31076 (Mükerrer).

Telli Yamamoto, G. \& Altun, D. (2020). Coronavirüs ve çevrimiçi (Online) eğitimin önlenemeyen yükselişi. Üniversite Araştırmaları Dergisi, 3(1), 25-34. DOI: 10.32329/uad.711110

UNESCO, (2020). Education: From disruption to recovery. (https://en.unesco.org/covid19/educationresponse). 31.05.2020 tarihinde erişilmiştir.

Wang, S. K. (2008). The effects of a synchronous communication tool (yahoo messenger) on online learners' sense of community and their multimedia authoring skills. Journal of Interactive Online Learning, 7(1), 59-74. Erişim adresi: http://www.ncolr.org/jiol/issues/pdf/7.1.4.pdf

WHO, (2020). WHO Director-General's opening remarks at the media briefing on COVID-19 - 11 March 2020. (https://www.who.int/dg/speeches/detail/who-director-general-s-openingremarks-at-the-media-briefing-on-covid-19---11-march-2020). 31.05.2020 tarihinde erişilmiştir.

Yıldız, E. \& Seferoğlu, S. S. (2020). Uzaktan eğitim öğrencilerinin çevrim içi teknolojilere yönelik öz yeterlik algılarının incelenmesi. Celal Bayar Üniversitesi Sosyal Bilimler Dergisi, 18(1), 33-46. Doi: 10.18026/cbayarsos.514904

Yılmaz, S. (2020). COVID-19'u kim üretti? Aşısı ne zaman bulunacak?.. (http://ankaenstitusu.com/covid-19u-kim-uretti-asisi-ne-zaman-bulunacak/). $\quad 31.05 .2020$ tarihinde erişilmiştir. 